\title{
Identification of novel BRCA1 large genomic rearrangements by a computational algorithm of amplicon-based Next- Generation Sequencing data
}

\author{
Arianna Nicolussi ${ }^{1}$, Francesca Belardinilli ${ }^{2}$, Valentina Silvestri ${ }^{2}$, Yasaman Mahdavian ${ }^{2}$, Virginia Valentini ${ }^{2}$, Sonia \\ D'Inzeo $^{3}$, Marialaura Petroni ${ }^{4}$, Massimo Zani ${ }^{2}$, Sergio Ferraro ${ }^{2}$, Stefano Di Giulio ${ }^{2}$, Francesca Fabretti ${ }^{2}$, Beatrice \\ Fratini $^{1}$, Angela Gradilone ${ }^{2}$, Laura Ottini ${ }^{2}$, Giuseppe Giannini \\ Anna Coppa \\ Carlo Capalbo ${ }^{2}$

Background: Genetic testing for BRCAl/2 germline mutations in hereditary breast/ovarian cancer patients requires screening for single nucleotide variants, small insertions/deletions and large genomic rearrangements (LGRs). These studies have long been run by Sanger sequencing and multiplex ligation-dependent probe amplification (MLPA). The recent introduction of next-generation sequencing (NGS) platforms dramatically improved the speed and the efficiency of DNA testing for nucleotide variants, while the possibility to correctly detect LGRs by this mean is still debated. The purpose of this study was to establish whether and to which extent the development of an analytical algorithm could help us translating NGS sequencing via an Ion Torrent PGM platform into a tool suitable to identify LGRs in hereditary breast-ovarian cancer patients. Methods: We first used NGS data of a group of 3 patients (training set), previously screened in our laboratory by conventional methods, to develop an algorithm for the calculation of the dosage quotient (DQ) to be compared with the Ion Reporter (IR) analysis. Then, we tested the optimized pipeline with a consecutive cohort of 85 uncharacterized probands (validation set) also subjected to MLPA analysis. Characterization of the breakpoints of three novel BRCA1 LGRs was obtained via long-range PCR and direct sequencing of the DNA products. Results: In our cohort, the newly defined DQ-based algorithm detected 3/3 BRCA1 LGRs, demonstrating $100 \%$ sensitivity and $100 \%$ negative predictive value (NPV) [95\% $\mathrm{Cl}: 87.6-99.9])$ compared to $2 / 3$ cases detected by IR (66.7\% sensitivity and $98.2 \%$ NPV [95\% Cl:85.6-99.9]). Interestingly, DQ and IR shared 12 positive results, but exons deletion calls matched only in 5 cases, two of which confirmed by MLPA. The breakpoints of the 3 
novel BRCA1 deletions, involving exons 16-17, 21-22 and 20, have been characterized. Conclusions: Our study defined a DQ-based algorithm to identify BRCA1 LGRs using NGS data. Whether confirmed on larger data sets, this tool could guide the selection of samples to be subjected to MLPA analysis, leading to significant savings in time and money. 


\section{Identification of novel $B R C A 1$ large genomic rearrangements by}

\section{2 a computational algorithm of amplicon-based Next-Generation}

\section{Sequencing data}

4

5 Arianna Nicolussi ${ }^{1}$; Francesca Belardinilli²; Valentina Silvestri²; Yasaman Mahdavian²; Virginia

6 Valentini²; Sonia D’Inzeo ${ }^{3}$; Marialaura Petroni ${ }^{4}$; Massimo Zani²; Sergio Ferraro²; Stefano Di

7 Giulio ${ }^{2}$; Francesca Fabretti²; Beatrice Fratini ${ }^{1}$; Angela Gradilone ${ }^{2}$; Laura Ottini²; Giuseppe

8 Giannini $^{2,5}$; Anna Coppa ${ }^{1 *}$ and Carlo Capalbo ${ }^{2 *}$

10 1Department of Experimental Medicine, University of Roma "La Sapienza”, Italy

11 2Department of Molecular Medicine, University of Roma "La Sapienza", Italy

$12{ }^{3}$ A.O. San Camillo Forlanini, U.O.C. Microbiology and Virology Laboratory, Roma, Italy

$13{ }^{4}$ Center for Life Nano Science@Sapienza, Istituto Italiano di Tecnologia, Roma, Italy

14 5Istituto Pasteur-Fondazione Cenci Bolognetti, Roma, Italy

$16 *$ These authors equally contributed to this work

17 Corresponding authors:

18 Dr. Anna Coppa, Department of Experimental Medicine, University of Roma "La Sapienza",

19 Italy. Email address: anna.coppa@uniroma1.it

20 Prof. Giuseppe Giannini, Department of Molecular Medicine, University of Roma “La

21 Sapienza”, Italy Email address: giuseppe.giannini@uniroma1.it 


\section{Abstract}

24 Background: Genetic testing for $B R C A 1 / 2$ germline mutations in hereditary breast/ovarian cancer patients requires screening for single nucleotide variants, small insertions/deletions and large genomic rearrangements (LGRs). These studies have long been run by Sanger sequencing and multiplex ligation-dependent probe amplification (MLPA). The recent introduction of nextgeneration sequencing (NGS) platforms dramatically improved the speed and the efficiency of DNA testing for nucleotide variants, while the possibility to correctly detect LGRs by this mean is still debated. The purpose of this study was to establish whether and to which extent the development of an analytical algorithm could help us translating NGS sequencing via an Ion Torrent PGM platform into a tool suitable to identify LGRs in hereditary breast-ovarian cancer patients.

34 Methods: We first used NGS data of a group of 3 patients (training set), previously screened in our laboratory by conventional methods, to develop an algorithm for the calculation of the dosage quotient (DQ) to be compared with the Ion Reporter (IR) analysis. Then, we tested the optimized pipeline with a consecutive cohort of 85 uncharacterized probands (validation set) also subjected to MLPA analysis. Characterization of the breakpoints of three novel BRCA1 LGRs was obtained via long-range PCR and direct sequencing of the DNA products.

Results: In our cohort, the newly defined DQ-based algorithm detected 3/3 BRCA1 LGRs, demonstrating 100\% sensitivity and 100\% negative predictive value (NPV) [95\% CI:87.6-99.9]) compared to $2 / 3$ cases detected by IR (66.7\% sensitivity and 98.2\% NPV [95\% CI:85.6-99.9]). 
44 cases, two of which confirmed by MLPA. The breakpoints of the 3 novel BRCA1 deletions, 45 involving exons 16-17, 21-22 and 20, have been characterized.

46 Conclusions: Our study defined a DQ-based algorithm to identify BRCA1 LGRs using NGS 47 data. Whether confirmed on larger data sets, this tool could guide the selection of samples to be subjected to MLPA analysis, leading to significant savings in time and money.

\section{Background}

Hereditary breast and ovarian cancer syndrome, caused by germline pathogenic mutations in the BRCA1 (MIM\#113705) or BRCA2 (MIM\#600185) genes, is characterized by an increased risk for breast, ovarian, pancreatic and other cancers (Palma et al., 2006). It has been recently

54 estimated that the cumulative risks of breast cancer to age 80 years was $72 \%$ for $B R C A 1$ and $5569 \%$ for $B R C A 2$ carriers (Kuchenbaecker et al., 2017). Differences in mutation type and site may 56 at least partially impact on cancer risk definition (Rebbeck et al., 2015; Coppa et al., 2018;

57 Rebbeck et al., 2018). BRCA1 and BRCA2 gene mutations are typically found in 25-30\% of the 58 breast cancer families subjected to genetic testing (Giannini et al., 2006; Economopoulou, Dimitriadis \& Psyrri, 2015). The relatively low rate of success in finding relevant pathogenic mutations in this settings is likely due to the contribution of other moderate-to-high penetrance breast cancer susceptibility genes (i.e., PALB2, ATM, CHK2) (Economopoulou, Dimitriadis \&

62 Psyrri, 2015; Coppa et al., 2018), or to the influence of low penetrance and risk-modifying 63 alleles (Couch et al., 2012; Ottini et al., 2013; Kuchenbaecker et al., 2014; Peterlongo et al., 64 2015), all of which needs to be taken into account for a more appropriate assessment of 65 individual cancer risk. For quite some time, the use of classical qualitative PCR-based techniques 66 incapable of detecting large genomic rearrangements (LGRs) also contributed to failures in the 
67 identification of $B R C A$ mutation carriers. Interestingly, the prevalence of $B R C A 1 / B R C A 2$ LGRs

68 varies greatly among different populations ranging from 0 to $27 \%$ of mutation positive families

69 in Iranian/French, Canadian, Dutch, Spanish, German, French and South Africa populations

70 (Gad et al., 2002; Hogervorst et al., 2003; Hartmann et al., 2004; Pietschmann et al., 2005;

71 Moisan et al., 2006; la Hoya et al., 2006; Sluiter \& van Rensburg, 2011). Relevant differences in

72 the frequency of BRCA1 LGRs have also been reported within the Italian population (Montagna

73 et al., 2003; Buffone et al., 2007). In general, BRCA2 LGRs are less frequent (Woodward et al.,

74 2005; Agata et al., 2005; Buffone et al., 2007), probably due to the lower density of Alu

75 sequences compared to BRCA1, which are involved in the genesis of LGRs (Smith et al., 1996).

76 Multiplex ligation-dependent probe amplification (MLPA) is the most commonly used technique

77 for the detection of large deletions/duplications in $B R C A 1 / 2$ genes.

78 The recent advances in sequencing technologies have increased the speed and efficiency of DNA

79 testing and the emergence of benchtop next-generation sequencing (NGS) instruments are

80 becoming the standard in molecular genetic diagnosis (Feliubadalo et al., 2013; Trujillano et al.,

81 2015). NGS is capable of sensitive detection of sequence variants, but may also be used for

82 detection of LGRs by the evaluation of Copy Number Variations (CNVs) (Tarabeux et al., 2014;

83 Enyedi et al., 2016; Schenkel et al., 2016; Schmidt et al., 2017). The CNVs assessment is mainly

84 performed using the sequencing read depth (RD) assessment approach, whose assumption is that

85 the RD signal is proportional to the number of copies of chromosomal segments present in that

86 specimen (Tan et al., 2014). The ability to detect CNVs from NGS multigene panel largely, but

87 not uniquely, depends on the library preparation, and target enrichment approaches based on

88 hybridization and capture seem to have better performances compared to amplicon-based

89 methods. In general, NGS data are not routinely used for CNVs detection in clinical settings for 
$90 B R C A$ mutation screenings, due to concerns related to library preparation protocols,

91 normalization procedures and employed software (Feliubadalo et al., 2013; Wallace, 2016).

92 Recently, we adopted the NGS Ion AmpliSeq ${ }^{\mathrm{TM}}$ BRCA1 and BRCA2 Panel to perform routine

93 BRCA1/2 mutation screening on the Ion PGM platform (Nicolussi et al., 2019). Here, we aimed

94 at establishing whether sequencing data generated by this approach could be processed by a

95 computational algorithm to efficiently predict the presence of LGRs, based on the dosage

96 quotient (DQ) calculation and the Ion Reporter (IR) analysis.

97

\section{Methods}

\section{Patients and DNA}

100 Families putatively affected by hereditary breast/ovarian cancer syndrome were recruited at the 101 Hereditary Tumors section of Policlinico Umberto I, University La Sapienza, between July 2015 102 and September 2017 and selected as previously described (Capalbo et al., 2006b,a; Coppa et al., 103 2014). Comprehensive pre-test counseling was offered to all probands and their family members 104 and informed consent was obtained. For each study participant, samples of blood or DNA from 105 peripheral blood leukocytes were collected. DNA from blood samples was extracted and 106 quantified as described by Nicolussi et al. (Nicolussi et al., 2019). All investigations were 107 approved by Ethics Committee of the University of Roma "La Sapienza" (Prot.: 88/18;

108 RIF.CE:4903, 31-01-2018) and conducted according to the principles outlined in the declaration 109 of Helsinki.

110 A retrospective group of 3 DNA samples, previously found positive for BRCA1 LGRs by MLPA 111 was used as a training set (TS). LGRs in the TS were as follows: sample BR59, BRCA1 exon 2311224 deletion (c.5407-?*(1_?)del); sample BR328, BRCA1 exon 18-19 deletion (c.5075- 
113 ?_5193+?del)(Buffone et al., 2007) and sample BR409, NBR2 exon1 and BRCA1 exon 1-2

114 deletion (NBR2del EX1_BRCA1 delEX1-2) (Coppa et al., 2018) (Table 1).

115 For NGS-based LGR analysis, a consecutive group of 127 NGS/MPLA negative samples have

116 been used to create a baseline and a prospective consecutive cohort of 85 uncharacterized

117 probands, validation set (VS), was studied.

118

119 Ion Torrent PGM sequencing

120 The target regions in the BRCA1 and BRCA2 genes were amplified using the Ion AmpliSeq ${ }^{\mathrm{TM}}$

121 BRCA1 and BRCA2 Panel (Life Technologies) according to the manufacturers' procedures and

122 processed as previously described (Belardinilli et al., 2015; Nicolussi et al., 2019).

123

124 Sanger sequencing

125 All clinical samples were sequenced for the entire coding regions by Sanger sequencing, using 126 an ABI PRISM DyeDeoxy Terminator Cycle Sequencing Kit and an ABI 3100 Genetic Analyzer

127 (Applied Biosystems, Warrington, UK). Reference sequence for BRCA1 was Genbank,

128 NM_007294.3, and reference sequence for BRCA2 was Genebank, NM_000059.3.

129

130 MLPA analyses

131 MLPA methodology (Schouten et al., 2002) was performed, according to the manufacturer's

132 instructions (MRC-Holland, Amsterdam, the Netherlands), to identify BRCA1/2 genomic 133 rearrangements. For the statistical analysis we transferred the size and the peak areas of each 134 sample to an Excel file. The peak areas of the expected MLPA products were evaluated by 
135 comparison with a normal control and by cumulative comparison of all samples within the same

136

137

138

139

140

141

142

143

144

145

146 147 Panel (DQB1) or by separately considering the three different pools of amplicons (DQB2). DQ

148

149

150

151

152

153

154

155

156

experiment (Buffone et al., 2007; Coppa et al., 2018).

\section{NGS-based LGRs Analysis}

LGRs in BRCA1 gene were studied by two distinct approaches: the manual calculation of the DQ and the IR platform. In the manual approach, DQ for each sample was calculated as follows: amplicon read count normalized on the $B R C A 1$ and $B R C A 2$ total reads/average of normalized amplicon read counts obtained from all samples. Specifically, we referred to DQA when amplicon counts were normalized $v s$ the coverage data of all samples run on the same single chip, and to DQB when amplicon counts were normalized vs coverage data obtained from a baseline built from 127 LGRs negative samples. In addition, DQB has been alternatively obtained either considering together all amplicons of the Ion AmpliSeq ${ }^{\mathrm{TM}}$ BRCA1 and BRCA2 value higher than mean plus 2 standard deviations (SD) was considered indicative of a duplication; DQ value lower than mean minus 2 SD was considered indicative of a deletion. Particular attention has been also payed to reduction of multiple consecutive amplicons, even when they failed to trespass the above defined thresholds.

In the IR approach, we create a user-defined CNV detection workflow by a tunable Ion Reporter ${ }^{\mathrm{TM}}$ Software algorithm based on Hidden Markov Model (HMM), that utilize normalized read coverage across amplicons to predict the copy number or ploidy (https://assets.thermofisher.com/TFS-Assets/LSG/brochures/CNV-Detection-by-Ion.pdf). The data coverage of 20 mutation-negative patients has been used as CNV baseline to analyze the 
157 samples of both TS and VS. We detected no BRCA2 LGR in both the TS and VS. Thus, our 158 analysis is necessarily limited to $B R C A 1$ LGRs.

159

160 DNA breakpoint analysis

161 Newly discovered $B R C A 1$ large deletions were validated by characterization of the genomic

162 breakpoints. Long-range PCR was performed according to the manufacturer's instructions using 163 the kit Platinum Taq DNA polymerases High Fidelity (Thermo Fisher) with the primers sitting 164 on closer undeleted exons as described in Table S2. PCR products were purified with ExoSAP165 IT (USB Corp., Cleveland, USA) according to the manufacturer's instructions and sequenced 166 using the ABI PRISM DyeDeoxy Terminator Cycle Sequencing Kit and an ABI 3100 Genetic 167 Analyzer (Applied Biosystems, Warrington, UK). Reference sequences for $B R C A 1$ and $B R C A 2$ 168 were Genebank NM_007294.3 and NM_000059.3, respectively.

170 Statistical analysis

171 Validation metrics were defined as: Accuracy $=(\mathrm{TP}+\mathrm{TN}) /(\mathrm{TP}+\mathrm{FP}+\mathrm{TN}+\mathrm{FN})$; Sensitivity $=$ $172 \mathrm{TP} /(\mathrm{TP}+\mathrm{FN}) ;$ Specificity $=\mathrm{TN} /(\mathrm{TN}+\mathrm{FP}) ; \mathrm{FDR}=\mathrm{FP} /(\mathrm{TP}+\mathrm{FP}) ;$ Negative Predictive Value $=$ $173 \mathrm{TN} /(\mathrm{TN}+\mathrm{FN})$, where $\mathrm{TP}=$ true positives, $\mathrm{TN}=$ true negatives, $\mathrm{FP}=$ false positives, $\mathrm{FN}=$ 174 false negatives. The confidence intervals (CIs) were calculated by the method of Wilson (1927) 175 (EB, 2019).

\section{Results}

\section{NGS-dependent LGR analyses}

179 To establish whether the data obtained by NGS via Ion AmpliSeq ${ }^{\mathrm{TM}}$ BRCA1 and BRCA2 Panel 
180 were suitable to identify copy number alterations in $B R C A 1$, we used data from three samples 181 (TS), already characterized in our laboratory for the presence of BRCA1 LGRs by MLPA (Table

182 1). The sequencing data of the TS were analyzed by a locally devised algorithm for the

183 calculation of the DQ and by our custom modified IR analysis, as described in materials and 184 methods. The intrarun DQ calculation (DQA), which includes normalization based on the 185 coverage data of the samples sequenced in the same chip, was always included to monitor the 186 variability eventually due to different batches of reagents or to time-related variables. In general, 187 however, we thought we could get improved resolution and reduced numbers of CNV false calls 188 by normalizing the coverage data of all amplicons of each sample $v s$ those obtained from a 189 reference set of 127 MLPA negative samples selected on the basis of their quality and uniformity 190 of the coverage (DQB analysis). This baseline has been used to perform two DQB calculations, 191 considering either all amplicons contained in the Ion AmpliSeq ${ }^{\mathrm{TM}}$ BRCA1 and BRCA2 Panel 192 (DQB1) or dividing them into the three subsets identified by the amplification primer pools 193 (DQB2).

194 As shown in Fig 1A, the DQA plot of the TS samples revealed the presence of peaks below the 195 thresholds, in samples BR328 and BR409 (corresponding to deletions of BRCA1 exons 18-19 196 and 1-2, respectively, in agreement with MLPA results). The DNA quality of BR59 sample was 197 rather low, as evidenced by the many peaks out of the threshold. Nevertheless, the DQB1 198 analysis evidenced values below the threshold for 3 consecutive amplicons (AMPL223551867, 199223530147 and 223954665), identifying BRCA1 exon 23-24 deletion (Fig.1B), already

200 discovered by MLPA analysis. Although they fail to trespass the threshold, the same consecutive 201 amplicons showed strongly reduced values also at DQA evaluation (Fig. 1A). Hence, the careful 202 examination of the two DQ calculations allowed us to identify all three BRCA1 LGRs in the TS. 
203 Also, the analysis performed by IR software detected the presence of $\mathrm{CNV}(\mathrm{CNV}=1)$ in the 204 proper regions in all three TS samples (Table 2). On this basis, we extended DQA, DQB and IR 205 analysis to a group of 85 consecutive samples (VS) negative for $B R C A 1 / 2$ pathogenic variants at 206 NGS analysis and compared it with MLPA results. Overall, DQA and DQB analysis resulted in 207 detection of positive calls in 33/85 (39\%) samples, while IR analysis detected CNVs in 29/85 208 (34\%) (Table 3). Interestingly, DQ and IR evaluation only shared 12 positive results, with exon 209 calls being not coincident in 7 of them and with a rather precise, although imperfect, indication 210 of the exons involved in the remaining 5 (Table S1). MLPA confirmed BRCA1 LGRs in 3/85 211 samples (Fig. 2): BR963 and BR1379, belonging to the small group of 5 DQ/IR double positive 212 samples, and BR1154 resulted DQ positive-IR negative. Therefore, DQ calculation resulted $213100 \%$ sensitive and displayed a 100\% NPV (95\% CI:87.6-99.9) (Table 3) in our VS, values not 214 reached by IR analysis, which failed in the identification of BR1154 (Table 2). Within DQ 215 analysis, the correct calls were more clearly defined by the DQB2 calculation (Fig. 3A, B, C). 216 The appropriateness of the deletions calls of DQ, IR and MLPA evaluations were confirmed by 217 the molecular characterization of the breakpoints, as described below.

\section{Characterization of LGRs}

220 Identification of the breakpoints characterizing the LGRs is important for several reasons, 221 including the possibility to develop diagnostic assays for segregation analyses in relatives. For 222 different reasons DQ, IR and MLPA analyses are not able to provide such detailed molecular 223 characterization of LGR. To define the breakpoints of the newly identified BRCAl LGRs, PCR 224 amplification of genomic DNA from the three samples and direct sequencing were performed. 
225 As shown in Fig. 4A, PCR amplification of genomic DNA from the BR963 patient resulted in an 226 aberrant fragment of approximately $1353 \mathrm{bp}$, whose direct sequencing confirmed loss of BRCA1 227 exons 21 and 22, possibly originating from an erroneous homologous recombination process 228 between an AluSq2 (Alu family, SINE class; chr17:41206762-41207066) and an AluSz (Alu 229 family, SINE class; chr17:41200521-41200834) motifs. The rearrangement involved a perfectly 230 repeated stretch of 24 bases and resulted in the deletion of 6228 nucleotides encompassing part 231 of IVS20, exons 21-22 and IVS22 (Fig. 4B, C). The BR963 proband was affected with breast 232 cancer at age 40 and belonged to HBC family. Segregation analysis demonstrated that the 233 mutation came from the maternal lineage (Fig. 5A). PCR amplification of genomic DNA from 234 BR1154 patient resulted in an aberrant fragment of approximately $872 \mathrm{bp}$ (also present in her 235 mother, sample BR1148), whose direct sequencing confirmed loss of BRCA1 exons 20, possibly 236 originating from an erroneous homologous recombination process between an AluY (Alu family, 237 SINE class; chr17:41205398-41205698) and an AluY (Alu family, SINE class; chr17:41205398238 41205698) motifs. The rearrangement involved a perfectly repeated stretch of 11 bases and 239 resulted in the deletion of 4173 nucleotides encompassing part of IVS19, exon 20 and IVS20

240 (Fig. 4D, E, F). The BR1154 proband was affected with ovarian cancer at age 52 and belonged to 241 a HBOC family (Fig. 5B). The segregation analysis demonstrated that the mutation originating 242 from the maternal lineage segregated in three individuals (Fig. 5B). Finally, PCR amplification 243 of genomic DNA from BR1379 patient, resulted in an aberrant fragment of approximately 2027

$244 \mathrm{bp}$, whose direct sequencing confirmed loss of $B R C A 1$ exons 16 and 17, possibly originated from 245 an erroneous homologous recombination process between an AluSp (Alu family, SINE class; 246 chr17:41224585-41224884) and an AluSg (Alu family, SINE class; chr17:41218424-41218724) 247 motif. The rearrangement involved a perfectly repeated stretch of 16 bases and resulted in the 
248 deletion of 6155 nucleotides encompassing part of IVS15, exons 16-17 and IVS17 (Fig. 4G, H,

249 I). The BR1379 proband was affected with bilateral breast cancer at age 42 and 58 and belonged

250 to a family with colon cancer and hepatomas cases (Fig. 5C).

251 In conclusion, our results in the VS allow us to propose an operative algorithm which

252 uses DQ calculation and IR analysis to select samples to be subjected to MLPA analysis, as

253 indicated in Fig. 6. Indeed, all DQ positive samples should be subjected to MLPA, while DQ and

254 IR double positive samples, sharing calls in the same regions, could be directly subjected to

255 second level confirmation assay or directly to breakpoint characterization. In principle, all DQ

256 negative samples (52 sample out of 85 in our VS) could be considered negative for LGRs, thus

257 completing the analysis at this step.

258

259 Discussion

260

A complete clinical level analysis of $B R C A 1$ and $B R C A 2$ in hereditary breast/ovarian

261 cancer includes the study of LGRs. Many methods have been used to identify LGRs, such as

262 fluorescent in-situ hybridization (FISH) and microarrays (Xia et al., 2018), Southern blot, long-

263 range PCR, quantitative multiplex PCR of short fragments (QMPSF) (Ewald et al., 2009),

264 semiquantitative multiplex PCR, real-time PCR, restriction analysis and sequencing (Armour et

265 al., 2002). All these methods are limited by their low throughput, time consuming, large amounts

266 of high molecular weight DNA request and several false negative results (Ewald et al., 2009).

267 More recently a multiplex PCR-based method that allows the determination of copy number status

268 of multiple loci in a single assay, has been developed by Multiplicom

269 (http://www.multiplicom.com) and described as a valid method (Concolino et al., 2014). However,

270 the MLPA represents the most widely used approach to scan for LGRs in BRCA1/2 genes (Ruiz 
271 de Garibay et al., 2012). The simultaneous detection of mutations and copy number alterations is

272 an attractive and useful prospect for clinical settings. In the last years the NGS-based approaches

273 for genetic testing offered a powerful alternative for BRCA1/2 mutation detection. However, the

274 specificity of this approach is still considered not completely satisfactory for a correct LGRs

275 detection. One of the most relevant aspects concerns the library preparation method, with the

276 amplicon-based approach having a lower specificity compared to target enrichment approaches

277 (Apessos et al., 2018). Here we reported the definition of an operative algorithm to use amplicon-

278 based Ion-PGM/Ampliseq $B R C A 1 / B R C A 2$ sequencing data to efficiently predict the occurrence of

279 BRCA1 LGRs. By comparison of the results obtained with DQ and IR analyses, we demonstrate

280 that DQ had 100\% sensitivity and 100\% NPV, at variance with IR analysis, which failed in the

281 identification of a $B R C A 1$ exon 20 deletion. This result is consistent with one known limitation of

282 the IR software, able to detect CNVs only if the region of interest is covered by more than one

283 amplicon (https://assets.thermofisher.com/TFS-Assets/LSG/brochures/CNV-Detection-by-

284 Ion.pdf). Indeed, BRCA1 exon 20, deleted in BR1154 sample, is covered by only one amplicon in

285 the Ion AmpliSeq ${ }^{\mathrm{TM}}$ BRCA1 and BRCA2 Panel, making IR incapable of calling this CNV.

286 Of course, a major caveat deals with the limited specificity and accuracy of our approach, which

287 could not overcome the limitations also reported by other groups (Feliubadalo et al., 2013; Pilato

288 et al., 2016). Thus, although our operative algorithm cannot fully substitute for MLPA analysis,

289 and if our data will be confirmed in larger data sets, we suggest that combined DQ and IR

290 analyses could be used for selecting samples to be subjected to MLPA analysis following the

291 flow chart depicted in Fig. 4, with significant savings in time and money.

292 Another important contribution of this paper is the molecular characterization of the three novel

$293 B R C A 1$ rearrangements up to providing their unique breakpoint coordinates. Deletion of exons 
29421 and 22 causing damage to the C-terminal BRCT domain of the BRCA1 protein has been 295 reported and characterized in Czech (Vasickova et al., 2007; Ticha et al., 2010) and Malay 296 population (Hasmad et al., 2015), but with different breakpoints. BRCA1 exon 20 deletion has

297 been described in Italian and Greek population (Montagna et al., 2003; Belogianni et al., 2004; 298 Armaou et al., 2007) but all different from each other and from our own, with respect to their 299 breakpoints. The BRCA1 exons 16-17 deletion, responsible of BRCA1 loss of function (Carvalho 300 et al., 2009), has been reported in Latin America/Caribbean population, but the breakpoints were

301 not provided by the authors (Judkins et al., 2012). Similar to many other cases (Mazoyer, 2005;

302 Buffone et al., 2007; Ewald et al., 2009), all three novel rearrangements described here, are 303 likely to be due to an erroneous homologous recombination event between perfectly matching 304 Alu repeats.

305

306 Conclusion

307 In conclusion, here we described a simple approach that require the use of a basic statistical 308 package such as Microsoft Excel, to predict the occurrence of LGRs by the analysis of NGS data 309 designed for Ion AmpliSeq ${ }^{\mathrm{TM}}$ BRCA1 and BRCA2 Panel/IT-PGM platform, applicable to all 310 NGS platforms in use to reduce the number of samples to be subjected to MLPA analysis. We 311 also characterized for the first time the breakpoints of three novel BRCA1 LGRs.

\section{Acknowledgements}

314 The authors would like to thank Dr. Alessandro Albiero for advice on data analysis. 315

316 Reference 
317 1. Agata S, Dalla Palma M, Callegaro M, Scaini MC, Menin C, Ghiotto C, Nicoletto O, Zavagno

318 G, Chieco-Bianchi L, D'Andrea E, Montagna M 2005. Large genomic deletions inactivate the 319 BRCA2 gene in breast cancer families. Journal of medical genetics 42:e64. DOI:

$320 \quad$ 10.1136/jmg.2005.032789.

321 2. Apessos A, Agiannitopoulos K, Pepe G, Tsaousis GN, Papadopoulou E, Metaxa-Mariatou V, 322 Tsirigoti A, Efstathiadou C, Markopoulos C, Xepapadakis G, Venizelos V, Tsiftsoglou A, 323 Natsiopoulos I, Nasioulas G 2018. Comprehensive BRCA mutation analysis in the Greek 324 population. Experience from a single clinical diagnostic center. Cancer genetics 220:1-12. 325 DOI: 10.1016/j.cancergen.2017.10.002.

326 3. Armaou S, Konstantopoulou I, Anagnostopoulos T, Razis E, Boukovinas I, Xenidis N, 327 Fountzilas G, Yannoukakos D 2007. Novel genomic rearrangements in the BRCA1 gene 328 detected in Greek breast/ovarian cancer patients. European Journal of Cancer 43:443-453. 329 DOI: 10.1016/j.ejca.2006.09.021.

330 4. Armour JAL, Barton DE, Cockburn DJ, Taylor GR 2002. The detection of large deletions or 331 duplications in genomic DNA. Human Mutation 20:325-337. DOI: 10.1002/humu.10133. 332 5. Belardinilli F, Capalbo C, Buffone A, Petroni M, Colicchia V, Ferraro S, Zani M, Nicolussi 333 A, D'Inzeo S, Coppa A, Screpanti I, Gulino A, Giannini G 2015. Validation of the Ion Torrent 334 PGM sequencing for the prospective routine molecular diagnostic of colorectal cancer. 335 Clinical biochemistry 48:908-910. DOI: 10.1016/j.clinbiochem.2015.04.003.

336 6. Belogianni I, Apessos A, Mihalatos M, Razi E, Labropoulos S, Petounis A, Gaki V, 337 Keramopoulos A, Pandis N, Kyriacou K, Hadjisavvas A, Kosmidis P, Yannoukakos D, 338 Nasioulas G 2004. Characterization of a novel large deletion and single point mutations in the 
339 BRCA1 gene in a Greek cohort of families with suspected hereditary breast cancer. $B M C$ $340 \quad$ Cancer 4:61. DOI: 10.1186/1471-2407-4-61.

341 7. Buffone A, Capalbo C, Ricevuto E, Sidoni T, Ottini L, Falchetti M, Cortesi E, Marchetti P, 342 Scambia G, Tomao S, Rinaldi C, Zani M, Ferraro S, Frati L, Screpanti I, Gulino A, Giannini 343 G 2007. Prevalence of BRCA1 and BRCA2 genomic rearrangements in a cohort of 344 consecutive Italian breast and/or ovarian cancer families. Breast Cancer Research and 345 Treatment 106:289-296. DOI: 10.1007/s10549-007-9499-6.

346 8. Capalbo C, Ricevuto E, Vestri A, Ristori E, Sidoni T, Buffone O, Adamo B, Cortesi E, 347 Marchetti P, Scambia G, Tomao S, Rinaldi C, Zani M, Ferraro S, Frati L, Screpanti I, Gulino 348 A, Giannini G 2006a. BRCA1 and BRCA2 genetic testing in Italian breast and/or ovarian 349 cancer families: mutation spectrum and prevalence and analysis of mutation prediction 350 models. Annals of oncology : official journal of the European Society for Medical Oncology / 351 ESMO 17 Suppl 7:vii34-40. DOI: 10.1093/annonc/md1947.

352 9. Capalbo C, Ricevuto E, Vestri A, Sidoni T, Buffone A, Cortesi E, Marchetti P, Scambia G, 353 Tomao S, Rinaldi C, Zani M, Ferraro S, Frati L, Screpanti I, Gulino A, Giannini G 2006 b. 354 Improving the accuracy of BRCA1/2 mutation prediction: validation of the novel country355 customized IC software. European journal of human genetics : EJHG 14:49-54. DOI: $356 \quad 10.1038 /$ sj.ejhg.5201511.

357 10. Carvalho M, Pino MA, Karchin R, Beddor J, Godinho-Netto M, Mesquita RD, Rodarte RS, 358 Vaz DC, Monteiro VA, Manoukian S, Colombo M, Ripamonti CB, Rosenquist R, Suthers G, 359 Borg A, Radice P, Grist SA, Monteiro ANA, Billack B 2009. Analysis of a set of missense, 360 frameshift, and in-frame deletion variants of BRCA1. Mutation research 660:1-11. DOI: $361 \quad$ 10.1016/j.mrfmmm.2008.09.017. 
362 11. Concolino P, Mello E, Minucci A, Santonocito C, Scambia G, Giardina B, Capoluongo E 363 2014. Advanced tools for BRCA1/2 mutational screening: comparison between two methods 364 for large genomic rearrangements (LGRs) detection. Clinical chemistry and laboratory 365 medicine 52:1119-1127. DOI: 10.1515/cclm-2013-1114.

366 12. Coppa A, Buffone A, Capalbo C, Nicolussi A, D'Inzeo S, Belardinilli F, Colicchia V, Petroni 367 M, Granato T, Midulla C, Zani M, Ferraro S, Screpanti I, Gulino A, Giannini G 2014. Novel 368 and recurrent BRCA2 mutations in Italian breast/ovarian cancer families widen the ovarian 369 cancer cluster region boundaries to exons 13 and 14. Breast Cancer Research and Treatment 370 148:629-635. DOI: 10.1007/s10549-014-3196-z.

371 13. Coppa A, Nicolussi A, D'Inzeo S, Capalbo C, Belardinilli F, Colicchia V, Petroni M, Zani M, 372 Ferraro S, Rinaldi C, Buffone A, Bartolazzi A, Screpanti I, Ottini L, Giannini G 2018.

373 Optimizing the identification of risk-relevant mutations by multigene panel testing in selected 374 hereditary breast/ovarian cancer families. Cancer medicine 7:46-55. DOI:

$375 \quad 10.1002 /$ cam4.1251.

376 14. Couch FJ, Antoniou AC, Ramus SJ, Kuchenbaecker KB, Soucy P, Beesley J, Chen X, Wang 377 X, Kirchhoff T, McGuffog L, Barrowdale D, Lee A, Healey S, Sinilnikova OM, Andrulis IL, 378 for OCGN, Ozcelik H, Mulligan AM, Thomassen M, Gerdes A-M, Skytte A-B, Kruse TA, 379 Caligo MA, Wachenfeldt von A, Barbany-Bustinza G, Loman N, Soller M, Ehrencrona H, 380 Karlsson P, for SWE-BRCA, Nathanson KL, Domchek SM, Jakubowska A, Lubinski J, 381 Jaworska K, Durda K, Zlowocka E, Huzarski T, Byrski T, Gronwald J, Cybulski C, Górski B, 382 Osorio A, Durán M, Tejada MI, Benítez J, Hamann U, for HEBON, van Os TA, van Leeuwen 383 FE, Meijers-Heijboer HEJ, Wijnen J, Blok MJ, Kets M, Hooning MJ, Oldenburg RA, Peock 384 S, Frost D, Ellis SD, Platte R, Fineberg E, Evans DG, Jacobs C, Eeles RA, Adlard J, 
385 Davidson R, Cole T, Cook J, Paterson J, Brewer C, Douglas F, Hodgson SV, Morrison PJ, 386 Walker L, Porteous ME, Kennedy MJ, for EMBRACE, Bove B, Godwin AK, Stoppa387 Lyonnet D, for GEMO Study Collaborators, Fassy-Colcombet M, Castera L, Cornelis F, 388 Mazoyer S, Léoné M, Boutry-Kryza N, Bressac-de Paillerets B, Caron O, Pujol P, Coupier I, 389 Delnatte C, Akloul L, Lynch HT, Snyder CL, Buys SS, Daly MB, Terry M, Chung WK, John 390 EM, Miron A, Southey MC, Hopper JL, Goldgar DE, Singer CF, Tea M-KM, Fink-Retter A, 391 Nielsen FC, Arason A, Shah S, Sarrel K, Robson ME, Piedmonte M, Phillips K, Basil J, 392 Rubinstein WS, Boggess J, Wakeley K, Ewart-Toland A, Montagna M, Isaacs C, Lazaro C, 393 Blanco I, Feliubadalo L, Brunet J, Gayther SA, Pharoah PPD, Odunsi KO, Karlan BY, Walsh 394 CS, Olah E, Teo SH, Ganz PA, Beattie MS, Dorfling CM, Díez O, Kwong A, Schmutzler RK, 395 Engel C, Meindl A, Ditsch N, Arnold N, Heidemann S, Niederacher D, Preisler-Adams S, 396 Gadzicki D, Varon-Mateeva R, Deissler H, Gehrig A, Sutter C, Kast K, Fiebig B, Heinritz W, 397 Caldés T, la Hoya de M, Muranen TA, Nevanlinna H, Tischkowitz MD, Spurdle AB, 398 Neuhausen SL, Ding YC, Lindor NM, Fredericksen Z, Pankratz VS, Peterlongo P, 399 Manoukian S, Peissel B, Zaffaroni D, Bernard L, Viel A, Giannini G, Varesco L, Radice P, 400 Greene MH, Easton DF, Chenevix-Trench G, for kConFab investigators, Offit K, Simard J, 401 on behalf of the Consortium of Investigators of Modifiers of BRCA1/2 2012. Common $402 \quad$ Variants at the 19p13.1 and ZNF365 Loci Are Associated with ER Subtypes of Breast Cancer 403 and Ovarian Cancer Risk in BRCA1 and BRCA2 Mutation Carriers. Cancer epidemiology, 404 biomarkers \& prevention : a publication of the American Association for Cancer Research, 405 cosponsored by the American Society of Preventive Oncology. DOI: 10.1158/1055-9965.EPI$406 \quad 11-0888$. 
407 15. EB W 2019. Probable Inference, the Law of Succession, and Statistical Inference. Journal of 408 the American Statistical Association:1-1.

409 16. Economopoulou P, Dimitriadis G, Psyrri A 2015. Beyond BRCA: new hereditary breast 410 cancer susceptibility genes. Cancer treatment reviews 41:1-8. DOI:

$411 \quad$ 10.1016/j.ctrv.2014.10.008.

412 17. Enyedi MZ, Jaksa G, Pintér L, Sükösd F, Gyuris Z, Hajdu A, Határvölgyi E, Priskin K, 413 Haracska L 2016. Simultaneous detection of BRCA mutations and large genomic 414 rearrangements in germline DNA and FFPE tumor samples. Oncotarget. DOI: $415 \quad 10.18632$ oncotarget. 11259.

416 18. Ewald IP, Ribeiro PLI, Palmero EI, Cossio SL, Giugliani R, Ashton-Prolla P 2009. Genomic 417 rearrangements in BRCA1 and BRCA2: A literature review. Genetics and molecular biology 418 32:437-446. DOI: 10.1590/S1415-47572009005000049.

419 19. Feliubadalo L, Lopez-Doriga A, Castellsagué E, del Valle J, Menéndez M, Tornero E, Montes 420 E, Cuesta R, Gómez C, Campos O, Pineda M, González S, Moreno V, Brunet J, Blanco I, 421 Serra E, Capellá G, Lazaro C 2013. Next-generation sequencing meets genetic diagnostics: 422 development of a comprehensive workflow for the analysis of BRCA1 and BRCA2 genes. 423 European journal of human genetics : EJHG 21:864-870. DOI: 10.1038/ejhg.2012.270. 424 20. Gad S, Caux-Moncoutier V, Pages-Berhouet S, Gauthier-Villars M, Coupier I, Pujol P, 425 Frenay M, Gilbert B, Maugard C, Bignon Y-J, Chevrier A, Rossi A, Fricker J-P, Nguyen TD, 426 Demange L, Aurias A, Bensimon A, Stoppa-Lyonnet D 2002. Significant contribution of 427 large BRCA1 gene rearrangements in 120 French breast and ovarian cancer families. 428 Oncogene 21:6841-6847. DOI: 10.1038/sj.onc.1205685. 
429 21. Giannini G, Capalbo C, Ristori E, Ricevuto E, Sidoni T, Buffone A, Cortesi E, Marchetti P, 430 Scambia G, Tomao S, Rinaldi C, Zani M, Ferraro S, Frati L, Screpanti I, Gulino A 2006. 431 Novel BRCA1 and BRCA2 germline mutations and assessment of mutation spectrum and 432 prevalence in Italian breast and/or ovarian cancer families. Breast Cancer Research and 433 Treatment 100:83-91. DOI: 10.1007/s10549-006-9225-9.

434 22. Hartmann C, John AL, Klaes R, Hofmann W, Bielen R, Koehler R, Janssen B, Bartram CR, 435 Arnold N, Zschocke J 2004. Large BRCA1 gene deletions are found in 3\% of German high436 risk breast cancer families. Human Mutation 24:534. DOI: 10.1002/humu.9291.

437 23. Hasmad HN, Sivanandan K, Lee V, Yip CH, Mohd Taib NA, Teo SH 2015. Identification of 438 a recurrent BRCA1 exon 21-22 genomic rearrangement in Malay breast cancer patients.

439 Clinical genetics 87:392-394. DOI: 10.1111/cge.12451.

440 24. Hogervorst FBL, Nederlof PM, Gille JJP, McElgunn CJ, Grippeling M, Pruntel R, Regnerus 441 R, van Welsem T, van Spaendonk R, Menko FH, Kluijt I, Dommering C, Verhoef S, 442 Schouten JP, Van't Veer LJ, Pals G 2003. Large genomic deletions and duplications in the 443 BRCA1 gene identified by a novel quantitative method. Cancer research 63:1449-1453. 444 25. Judkins T, Rosenthal E, Arnell C, Burbidge LA, Geary W, Barrus T, Schoenberger J, Trost J, 445 Wenstrup RJ, Roa BB 2012. Clinical significance of large rearrangements in BRCA1 and $446 \quad$ BRCA2. Cancer 118:5210-5216. DOI: 10.1002/cncr.27556.

447 26. Kuchenbaecker KB, Hopper JL, Barnes DR, Phillips K-A, Mooij TM, Roos-Blom M-J, Jervis 448 S, van Leeuwen FE, Milne RL, Andrieu N, Goldgar DE, Terry MB, Rookus MA, Easton DF, 449 Antoniou AC, BRCA1 and BRCA2 Cohort Consortium, McGuffog L, Evans DG, Barrowdale 450 D, Frost D, Adlard J, Ong K-R, Izatt L, Tischkowitz M, Eeles R, Davidson R, Hodgson S, 451 Ellis S, Nogues C, Lasset C, Stoppa-Lyonnet D, Fricker J-P, Faivre L, Berthet P, Hooning 
452 MJ, van der Kolk LE, Kets CM, Adank MA, John EM, Chung WK, Andrulis IL, Southey M, 453 Daly MB, Buys SS, Osorio A, Engel C, Kast K, Schmutzler RK, Caldés T, Jakubowska A, 454 Simard J, Friedlander ML, McLachlan S-A, Machackova E, Foretova L, Tan YY, Singer CF, 455 Olah E, Gerdes A-M, Arver B, Olsson H 2017. Risks of Breast, Ovarian, and Contralateral 456 Breast Cancer for BRCA1 and BRCA2 Mutation Carriers. JAMA : the journal of the 457 American Medical Association 317:2402-2416. DOI: 10.1001/jama.2017.7112.

458 27. Kuchenbaecker KB, Neuhausen SL, Robson M, Barrowdale D, McGuffog L, Mulligan AM, 459 Andrulis IL, Spurdle AB, Schmidt MK, Schmutzler RK, Engel C, Wappenschmidt B, 460 Nevanlinna H, Thomassen M, Southey M, Radice P, Ramus SJ, Domchek SM, Nathanson 461 KL, Lee A, Healey S, Nussbaum RL, Rebbeck TR, Arun BK, James P, Karlan BY, Lester J, 462 Cass I, Breast Cancer Family Registry, Terry MB, Daly MB, Goldgar DE, Buys SS, 463 Janavicius R, Tihomirova L, Tung N, Dorfling CM, van Rensburg EJ, Steele L, O Hansen von 464 T, Ejlertsen B, Gerdes A-M, Nielsen FC, Dennis J, Cunningham J, Hart S, Slager S, Osorio A, 465 Benítez J, Durán M, Weitzel JN, Tafur I, Hander M, Peterlongo P, Manoukian S, Peissel B, 466 Roversi G, Scuvera G, Bonanni B, Mariani P, Volorio S, Dolcetti R, Varesco L, Papi L, 467 Tibiletti MG, Giannini G, Fostira F, Konstantopoulou I, Garber J, Hamann U, Donaldson A, 468 Brewer C, Foo C, Evans DG, Frost D, Eccles D, EMBRACE Study, Douglas F, Brady A, 469 Cook J, Tischkowitz M, Adlard J, Barwell J, Ong K-R, Walker L, Izatt L, Side LE, Kennedy 470 MJ, Rogers MT, Porteous ME, Morrison PJ, Platte R, Eeles R, Davidson R, Hodgson S, Ellis 471 S, Godwin AK, Rhiem K, Meindl A, Ditsch N, Arnold N, Plendl H, Niederacher D, Sutter C, 472 Steinemann D, Bogdanova-Markov N, Kast K, Varon-Mateeva R, Wang-Gohrke S, Gehrig A, 473 Markiefka B, Buecher B, Lefol C, Stoppa-Lyonnet D, Rouleau E, Prieur F, Damiola F, 474 GEMO Study Collaborators, Barjhoux L, Faivre L, Longy M, Sevenet N, Sinilnikova OM, 
475 Mazoyer S, Bonadona V, Caux-Moncoutier V, Isaacs C, Van Maerken T, Claes K, Piedmonte

476 M, Andrews L, Hays J, Rodriguez GC, Caldés T, la Hoya de M, Khan S, Hogervorst FBL,

477 Aalfs CM, de Lange JL, Meijers-Heijboer HEJ, van der Hout AH, Wijnen JT, van Roozendaal

478 KEP, Mensenkamp AR, van den Ouweland AMW, van Deurzen CHM, van der Luijt RB,

479 HEBON, Olah E, Díez O, Lazaro C, Blanco I, Teulé A, Menéndez M, Jakubowska A,

480 Lubinski J, Cybulski C, Gronwald J, Jaworska-Bieniek K, Durda K, Arason A, Maugard C,

481 Soucy P, Montagna M, Agata S, Teixeira MR, kConFab Investigators, Olswold C, Lindor N,

482 Pankratz VS, Hallberg E, Wang X, Szabo CI, Vijai J, Jacobs L, Corines M, Lincoln A, Berger

483 A, Fink-Retter A, Singer CF, Rappaport C, Kaulich DG, Pfeiler G, Tea M-K, Phelan CM, Mai

484 PL, Greene MH, Rennert G, Imyanitov EN, Glendon G, Toland AE, Bojesen A, Pedersen IS,

485 Jensen UB, Caligo MA, Friedman E, Berger R, Laitman Y, Rantala J, Arver B, Loman N,

486 Borg A, Ehrencrona H, Olopade OI, Simard J, Easton DF, Chenevix-Trench G, Offit K,

487 Couch FJ, Antoniou AC, CIMBA 2014. Associations of common breast cancer susceptibility

488 alleles with risk of breast cancer subtypes in BRCA1 and BRCA2 mutation carriers. Breast

489 cancer research : BCR 16:3416. DOI: 10.1186/s13058-014-0492-9.

490 28. la Hoya de M, Gutiérrez-Enríquez S, Velasco E, Osorio A, Sánchez de Abajo A, Vega A,

491 Salazar R, Esteban E, Llort G, González-Sarmiento R, Carracedo Á, Benítez J, Miner C, Díez

492 O, Díaz-Rubio E, Caldés T 2006. Genomic rearrangements at the BRCA1 locus in Spanish

493 families with breast/ovarian cancer. Clinical chemistry 52:1480-1485. DOI:

$494 \quad 10.1373 /$ clinchem.2006.070110.

495 29. Mazoyer S 2005. Genomic rearrangements in theBRCA1 andBRCA2 genes. Human Mutation 496 25:415-422. DOI: 10.1002/humu.20169. 
497 30. Moisan A-M, Fortin J, Dumont M, Samson C, Bessette P, Chiquette J, Laframboise R, Lépine 498 J, Lespérance B, Pichette R, Plante M, Provencher L, Voyer P, Goldgar D, Bridge P, Simard J 499 2006. No Evidence of BRCA1/2 genomic rearrangements in high-risk French-Canadian 500 breast/ovarian cancer families. Genetic testing 10:104-115. DOI: 10.1089/gte.2006.10.104.

501 31. Montagna M, Dalla Palma M, Menin C, Agata S, De Nicolo A, Chieco-Bianchi L, D'Andrea 502 E 2003. Genomic rearrangements account for more than one-third of the BRCA1 mutations in 503 northern Italian breast/ovarian cancer families. Human molecular genetics 12:1055-1061.

504 32. Nicolussi A, Belardinilli F, Mahdavian Y, Colicchia V, D'Inzeo S, Petroni M, Zani M, Ferraro 505 S, Valentini V, Ottini L, Giannini G, Capalbo C, Coppa A 2019. Next-generation sequencing 506 of BRCA1 and BRCA2 genes for rapid detection of germline mutations in hereditary 507 breast/ovarian cancer. PeerJ 7:e6661. DOI: 10.7717/peerj.6661.

508 33. Ottini L, Silvestri V, Saieva C, Rizzolo P, Zanna I, Falchetti M, Masala G, Navazio AS, 509 Graziano V, Bianchi S, Manoukian S, Barile M, Peterlongo P, D’Amico C, Varesco L, 510 Tommasi S, Russo A, Giannini G, Cortesi L, Viel A, Montagna M, Radice P, Palli D 2013. 511 Association of low-penetrance alleles with male breast cancer risk and clinicopathological 512 characteristics: results from a multicenter study in Italy. Breast Cancer Research and 513 Treatment 138:861-868. DOI: 10.1007/s10549-013-2459-4.

514 34. Palma M, Ristori E, Ricevuto E, Giannini G, Gulino A 2006. BRCA1 and BRCA2: the 515 genetic testing and the current management options for mutation carriers. Critical reviews in 516 oncology/hematology 57:1-23. DOI: 10.1016/j.critrevonc.2005.05.003.

517 35. Peterlongo P, Chang-Claude J, Moysich KB, Rudolph A, Schmutzler RK, Simard J, Soucy P, 518 Eeles RA, Easton DF, Hamann U, Wilkening S, Chen B, Rookus MA, Schmidt MK, van der 519 Baan FH, Spurdle AB, Walker LC, Lose F, Maia A-T, Montagna M, Matricardi L, Lubinski J, 
520 Jakubowska A, Gómez Garcia EB, Olopade OI, Nussbaum RL, Nathanson KL, Domchek 521 SM, Rebbeck TR, Arun BK, Karlan BY, Orsulic S, Lester J, Chung WK, Miron A, Southey

522 MC, Goldgar DE, Buys SS, Janavicius R, Dorfling CM, van Rensburg EJ, Ding YC,

523 Neuhausen SL, Hansen TVO, Gerdes A-M, Ejlertsen B, Jønson L, Osorio A, Martínez-

524 Bouzas C, Benítez J, Conway EE, Blazer KR, Weitzel JN, Manoukian S, Peissel B, Zaffaroni

525 D, Scuvera G, Barile M, Ficarazzi F, Mariette F, Fortuzzi S, Viel A, Giannini G, Papi L, 526 Martayan A, Tibiletti MG, Radice P, Vratimos A, Fostira F, Garber JE, Donaldson A, Brewer

527 C, Foo C, Evans DGR, Frost D, Eccles D, Brady A, Cook J, Tischkowitz M, Adlard J,

528 Barwell J, Walker L, Izatt L, Side LE, Kennedy MJ, Rogers MT, Porteous ME, Morrison PJ, 529 Platte R, Davidson R, Hodgson SV, Ellis S, Cole T, EMBRACE, Godwin AK, Claes K, Van 530 Maerken T, Meindl A, Gehrig A, Sutter C, Engel C, Niederacher D, Steinemann D, Plendl H, 531 Kast K, Rhiem K, Ditsch N, Arnold N, Varon-Mateeva R, Wappenschmidt B, Wang-Gohrke 532 S, Bressac-de Paillerets B, Buecher B, Delnatte C, Houdayer C, Stoppa-Lyonnet D, Damiola 533 F, Coupier I, Barjhoux L, Venat-Bouvet L, Golmard L, Boutry-Kryza N, Sinilnikova OM, 534 Caron O, Pujol P, Mazoyer S, Belotti M, GEMO Study Collaborators, Piedmonte M, 535 Friedlander ML, Rodriguez GC, Copeland LJ, la Hoya de M, Segura PP, Nevanlinna H, 536 Aittomaki K, van Os TAM, Meijers-Heijboer HEJ, van der Hout AH, Vreeswijk MPG, 537 Hoogerbrugge N, Ausems MGEM, van Doorn HC, Collée JM, HEBON, Olah E, Díez O, 538 Blanco I, Lazaro C, Brunet J, Feliubadalo L, Cybulski C, Gronwald J, Durda K, Jaworska539 Bieniek K, Sukiennicki G, Arason A, Chiquette J, Teixeira MR, Olswold C, Couch FJ, Lindor 540 NM, Wang X, Szabo CI, Offit K, Corines M, Jacobs L, Robson ME, Zhang L, Joseph V, 541 Berger A, Singer CF, Rappaport C, Kaulich DG, Pfeiler G, Tea M-KM, Phelan CM, Greene 542 MH, Mai PL, Rennert G, Mulligan AM, Glendon G, Tchatchou S, Andrulis IL, Toland AE, 
543 Bojesen A, Pedersen IS, Thomassen M, Jensen UB, Laitman Y, Rantala J, Wachenfeldt von 544 A, Ehrencrona H, Askmalm MS, Borg A, Kuchenbaecker KB, McGuffog L, Barrowdale D, 545 Healey S, Lee A, Pharoah PDP, Chenevix-Trench G, kConFab Investigators, Antoniou AC, 546 Friedman E 2015. Candidate genetic modifiers for breast and ovarian cancer risk in BRCA1 547 and BRCA2 mutation carriers. Cancer epidemiology, biomarkers \& prevention : a publication 548 of the American Association for Cancer Research, cosponsored by the American Society of 549 Preventive Oncology 24:308-316. DOI: 10.1158/1055-9965.EPI-14-0532.

550 36. Pietschmann A, Mehdipour P, Atri M, Hofmann W, Hosseini-Asl SS, Scherneck S, Mundlos 551 S, Peters H 2005. Mutation analysis of BRCA1 and BRCA2 genes in Iranian high risk breast 552 cancer families. Journal of cancer research and clinical oncology 131:552-558. DOI: $553 \quad 10.1007 / \mathrm{s} 00432-005-0678-8$.

554 37. Pilato B, Pinto R, De Summa S, Petriella D, Lacalamita R, Danza K, Paradiso A, Tommasi S 555 2016. BRCA1-2 diagnostic workflow from next-generation sequencing technologies to 556 variant identification and final report. Genes, chromosomes \& cancer 55:803-813. DOI: $557 \quad 10.1002 /$ gcc.22383.

558 38. Rebbeck TR, Friebel TM, Friedman E, Hamann U, Huo D, Kwong A, Olah E, Olopade OI, 559 Solano AR, Teo SH, Thomassen M, Weitzel JN, Chan TL, Couch FJ, Goldgar DE, Kruse TA, 560 Palmero EI, Park SK, Torres D, van Rensburg EJ, McGuffog L, Parsons MT, Leslie G, Aalfs 561 CM, Abugattas J, Adlard J, Agata S, Aittomaki K, Andrews L, Andrulis IL, Arason A, Arnold 562 N, Arun BK, Asseryanis E, Auerbach L, Azzollini J, Balmaña J, Barile M, Barkardottir RB, 563 Barrowdale D, Benítez J, Berger A, Berger R, Blanco AM, Blazer KR, Blok MJ, Bonadona 564 V, Bonanni B, Bradbury AR, Brewer C, Buecher B, Buys SS, Caldés T, Caliebe A, Caligo 565 MA, Campbell I, Caputo SM, Chiquette J, Chung WK, Claes KBM, Collée JM, Cook J, 
566 Davidson R, la Hoya de M, De Leeneer K, de Pauw A, Delnatte C, Díez O, Ding YC, Ditsch 567 N, Domchek SM, Dorfling CM, Velazquez C, Dworniczak B, Eason J, Easton DF, Eeles R, 568 Ehrencrona H, Ejlertsen B, EMBRACE, Engel C, Engert S, Evans DG, Faivre L, Feliubadalo 569 L, Ferrer SF, Foretova L, Fowler J, Frost D, Galvão HCR, Ganz PA, Garber J, Gauthier570 Villars M, Gehrig A, GEMO Study Collaborators, Gerdes A-M, Gesta P, Giannini G, Giraud 571 S, Glendon G, Godwin AK, Greene MH, Gronwald J, Gutierrez-Barrera A, Hahnen E, Hauke 572 J, HEBON, Henderson A, Hentschel J, Hogervorst FBL, Honisch E, Imyanitov EN, Isaacs C, 573 Izatt L, Izquierdo A, Jakubowska A, James P, Janavicius R, Jensen UB, John EM, Vijai J, 574 Kaczmarek K, Karlan BY, Kast K, Investigators K, Kim S-W, Konstantopoulou I, Korach J, 575 Laitman Y, Lasa A, Lasset C, Lazaro C, Lee A, Lee MH, Lester J, Lesueur F, Liljegren A, 576 Lindor NM, Longy M, Loud JT, Lu KH, Lubinski J, Machackova E, Manoukian S, Mari V, 577 Martínez-Bouzas C, Matrai Z, Mebirouk N, Meijers-Heijboer HEJ, Meindl A, Mensenkamp 578 AR, Mickys U, Miller A, Montagna M, Moysich KB, Mulligan AM, Musinsky J, Neuhausen 579 SL, Nevanlinna H, Ngeow J, Nguyen HP, Niederacher D, Nielsen HR, Nielsen FC, Nussbaum 580 RL, Offit K, Öfverholm A, Ong K-R, Osorio A, Papi L, Papp J, Pasini B, Pedersen IS, 581 Peixoto A, Peruga N, Peterlongo P, Pohl E, Pradhan N, Prajzendanc K, Prieur F, Pujol P, 582 Radice P, Ramus SJ, Rantala J, Rashid MU, Rhiem K, Robson M, Rodriguez GC, Rogers 583 MT, Rudaitis V, Schmidt AY, Schmutzler RK, Senter L, Shah PD, Sharma P, Side LE, 584 Simard J, Singer CF, Skytte A-B, Slavin TP, Snape K, Sobol H, Southey M, Steele L, 585 Steinemann D, Sukiennicki G, Sutter C, Szabo CI, Tan YY, Teixeira MR, Terry MB, Teulé 586 A, Thomas A, Thull DL, Tischkowitz M, Tognazzo S, Toland AE, Topka S, Trainer AH, 587 Tung N, van Asperen CJ, van der Hout AH, van der Kolk LE, van der Luijt RB, Van 588 Heetvelde M, Varesco L, Varon-Mateeva R, Vega A, Villarreal-Garza C, Wachenfeldt von A, 
589 Walker L, Wang-Gohrke S, Wappenschmidt B, Weber BHF, Yannoukakos D, Yoon S-Y, 590 Zanzottera C, Zidan J, Zorn KK, Hutten Selkirk CG, Hulick PJ, Chenevix-Trench G, Spurdle 591 AB, Antoniou AC, Nathanson KL 2018. Mutational spectrum in a worldwide study of 29,700 592 families with BRCA1 or BRCA2 mutations. Human Mutation 39:593-620. DOI:

$593 \quad 10.1002 /$ humu.23406.

594 39. Rebbeck TR, Mitra N, Wan F, Healey S, McGuffog L, Chenevix-Trench G, Easton DF, 595 Antoniou AC, Nathanson KL, CIMBA Consortium, Laitman Y, Kushnir A, Paluch-Shimon S, 596 Berger R, Zidan J, Friedman E, Ehrencrona H, Stenmark-Askmalm M, Einbeigi Z, Loman N, 597 Harbst K, Rantala J, Melin B, Huo D, Olopade OI, Seldon J, Ganz PA, Nussbaum RL, Chan 598 SB, Odunsi K, Gayther SA, Domchek SM, Arun BK, Lu KH, Mitchell G, Karlan BY, Walsh 599 C, Lester J, Godwin AK, Pathak H, Ross E, Daly MB, Whittemore AS, John EM, Miron A, 600 Terry MB, Chung WK, Goldgar DE, Buys SS, Janavicius R, Tihomirova L, Tung N, Dorfling 601 CM, van Rensburg EJ, Steele L, Neuhausen SL, Ding YC, Ejlertsen B, Gerdes A-M, Hansen 602 TVO, Ramón y Cajal T, Osorio A, Benítez J, Godino J, Tejada MI, Durán M, Weitzel JN, 603 Bobolis KA, Sand SR, Fontaine A, Savarese A, Pasini B, Peissel B, Bonanni B, Zaffaroni D, 604 Vignolo-Lutati F, Scuvera G, Giannini G, Bernard L, Genuardi M, Radice P, Dolcetti R, 605 Manoukian S, Pensotti V, Gismondi V, Yannoukakos D, Fostira F, Garber J, Torres D, Rashid 606 MU, Hamann U, Peock S, Frost D, Platte R, Evans DG, Eeles R, Davidson R, Eccles D, Cole 607 T, Cook J, Brewer C, Hodgson S, Morrison PJ, Walker L, Porteous ME, Kennedy MJ, Izatt L, 608 Adlard J, Donaldson A, Ellis S, Sharma P, Schmutzler RK, Wappenschmidt B, Becker A, 609 Rhiem K, Hahnen E, Engel C, Meindl A, Engert S, Ditsch N, Arnold N, Plendl HJ, 610 Mundhenke C, Niederacher D, Fleisch M, Sutter C, Bartram CR, Dikow N, Wang-Gohrke S, 611 Gadzicki D, Steinemann D, Kast K, Beer M, Varon-Mateeva R, Gehrig A, Weber BH, 
612 Stoppa-Lyonnet D, Sinilnikova OM, Mazoyer S, Houdayer C, Belotti M, Gauthier-Villars M,

613 Damiola F, Boutry-Kryza N, Lasset C, Sobol H, Peyrat J-P, Muller D, Fricker J-P, Collonge-

614 Rame M-A, Mortemousque I, Nogues C, Rouleau E, Isaacs C, De Paepe A, Poppe B, Claes

615 K, De Leeneer K, Piedmonte M, Rodriguez G, Wakely K, Boggess J, Blank SV, Basil J,

616 Azodi M, Phillips K-A, Caldés T, la Hoya de M, Romero A, Nevanlinna H, Aittomaki K, van

617 der Hout AH, Hogervorst FBL, Verhoef S, Collée JM, Seynaeve C, Oosterwijk JC, Gille JJP,

618 Wijnen JT, Gómez Garcia EB, Kets CM, Ausems MGEM, Aalfs CM, Devilee P,

619 Mensenkamp AR, Kwong A, Olah E, Papp J, Díez O, Lazaro C, Darder E, Blanco I, Salinas

620 M, Jakubowska A, Lubinski J, Gronwald J, Jaworska-Bieniek K, Durda K, Sukiennicki G,

621 Huzarski T, Byrski T, Cybulski C, Toloczko-Grabarek A, Złowocka-Perłowska E, Menkiszak

622 J, Arason A, Barkardottir RB, Simard J, Laframboise R, Montagna M, Agata S, Alducci E,

623 Peixoto A, Teixeira MR, Spurdle AB, Lee MH, Park SK, Kim S-W, Friebel TM, Couch FJ,

624 Lindor NM, Pankratz VS, Guidugli L, Wang X, Tischkowitz M, Foretova L, Vijai J, Offit K,

625 Robson M, Rau-Murthy R, Kauff N, Fink-Retter A, Singer CF, Rappaport C, Gschwantler-

626 Kaulich D, Pfeiler G, Tea M-K, Berger A, Greene MH, Mai PL, Imyanitov EN, Toland AE,

627 Senter L, Bojesen A, Pedersen IS, Skytte A-B, Sunde L, Thomassen M, Moeller ST, Kruse

628 TA, Jensen UB, Caligo MA, Aretini P, Teo SH, Selkirk CG, Hulick PJ, Andrulis I 2015.

629 Association of type and location of BRCA1 and BRCA2 mutations with risk of breast and

630 ovarian cancer. JAMA : the journal of the American Medical Association 313:1347-1361.

631 DOI: $10.1001 /$ jama.2014.5985.

632 40. Ruiz de Garibay G, Gutiérrez-Enríquez S, Garre P, Bonache S, Romero A, Palomo L,

633 Sánchez de Abajo A, Benítez J, Balmaña J, Pérez-Segura P, Díaz-Rubio E, Díez O, Caldés T,

634 Hoya M 2012. Characterization of four novel BRCA2 large genomic rearrangements in 
635 Spanish breast/ovarian cancer families: review of the literature, and reevaluation of the 636 genetic mechanisms involved in their origin. Breast Cancer Research and Treatment. DOI:

$637 \quad 10.1007 / \mathrm{s} 10549-011-1909-0$.

638 41. Schenkel LC, Kerkhof J, Stuart A, Reilly J, Eng B, Woodside C, Levstik A, Howlett CJ, 639 Rupar AC, Knoll JHM, Ainsworth P, Waye JS, Sadikovic B 2016. Clinical Next-Generation 640 Sequencing Pipeline Outperforms a Combined Approach Using Sanger Sequencing and 641 Multiplex Ligation-Dependent Probe Amplification in Targeted Gene Panel Analysis. The 642 Journal of molecular diagnostics : JMD 18:657-667. DOI: 10.1016/j.jmoldx.2016.04.002.

643 42. Schmidt AY, Hansen TVO, Ahlborn LB, Jønson L, Yde CW, Nielsen FC 2017. Next644 Generation Sequencing-Based Detection of Germline Copy Number Variations in 645 BRCA1/BRCA2: Validation of a One-Step Diagnostic Workflow. The Journal of molecular 646 diagnostics : JMD 19:809-816. DOI: 10.1016/j.jmoldx.2017.07.003.

647 43. Schouten JP, McElgunn CJ, Waaijer R, Zwijnenburg D, Diepvens F, Pals G 2002. Relative 648 quantification of 40 nucleic acid sequences by multiplex ligation-dependent probe 649 amplification. Nucleic acids research 30:e57.

650 44. Sluiter MD, van Rensburg EJ 2011. Large genomic rearrangements of the BRCA1 and 651 BRCA2 genes: review of the literature and report of a novel BRCA1 mutation. Breast Cancer 652 Research and Treatment 125:325-349. DOI: 10.1007/s10549-010-0817-z.

653 45. Smith TM, Lee MK, Szabo CI, Jerome N, McEuen M, Taylor M, Hood L, King MC 1996. 654 Complete genomic sequence and analysis of $117 \mathrm{~kb}$ of human DNA containing the gene 655 BRCA1. Genome research 6:1029-1049. 
656 46. Tan R, Wang Y, Kleinstein SE, Liu Y, Zhu X, Guo H, Jiang Q, Allen AS, Zhu M 2014. An

657 evaluation of copy number variation detection tools from whole-exome sequencing data.

658 Human Mutation 35:899-907. DOI: 10.1002/humu.22537.

659 47. Tarabeux J, Zeitouni B, Moncoutier V, Tenreiro H, Abidallah K, Lair S, Legoix-Né P, Leroy

660 Q, Rouleau E, Golmard L, Barillot E, Stern M-H, Rio-Frio T, Stoppa-Lyonnet D, Houdayer C

661 2014. Streamlined ion torrent PGM-based diagnostics: BRCA1 and BRCA2 genes as a model.

662 European journal of human genetics : EJHG 22:535-541. DOI: 10.1038/ejhg.2013.181.

663 48. Ticha I, Kleibl Z, Stribrna J, Kotlas J, Zimovjanova M, Mateju M, Zikan M, Pohlreich P

664 2010. Screening for genomic rearrangements in BRCA1 and BRCA2 genes in Czech high-

665 risk breast/ovarian cancer patients: high proportion of population specific alterations in

666 BRCA1 gene. Breast Cancer Research and Treatment 124:337-347. DOI: 10.1007/s10549-

$667 \quad 010-0745-y$.

668 49. Trujillano D, Weiss MER, Schneider J, Köster J, Papachristos EB, Saviouk V, Zakharkina T,

669 Nahavandi N, Kovacevic L, Rolfs A 2015. Next-generation sequencing of the BRCA1 and

670 BRCA2 genes for the genetic diagnostics of hereditary breast and/or ovarian cancer. The

671 Journal of molecular diagnostics : JMD 17:162-170. DOI: 10.1016/j.jmoldx.2014.11.004.

672 50. Vasickova P, Machackova E, Lukesova M, Damborsky J, Horky O, Pavlu H, Kuklova J,

673 Kosinova V, Navratilova M, Foretova L 2007. High occurrence of BRCA1 intragenic

674 rearrangements in hereditary breast and ovarian cancer syndrome in the Czech Republic.

675 BMC medical genetics 8:32. DOI: 10.1186/1471-2350-8-32.

676 51. Wallace AJ 2016. New challenges for BRCA testing: a view from the diagnostic laboratory.

677 European journal of human genetics : EJHG 24 Suppl 1:S10-8. DOI: 10.1038/ejhg.2016.94. 
678 52. Woodward AM, Davis TA, Silva AGS, Kirk JA, Leary JA, kConFab Investigators 2005.

679 Large genomic rearrangements of both BRCA2 and BRCA1 are a feature of the inherited

680 breast/ovarian cancer phenotype in selected families. Journal of medical genetics 42:e31.

681 DOI: $10.1136 /$ jmg.2004.027961.

682 53. Xia LC, Bell JM, Wood-Bouwens C, Chen JJ, Zhang NR, Ji HP 2018. Identification of large

683 rearrangements in cancer genomes with barcode linked reads. Nucleic acids research 46:e19.

684 DOI: $10.1093 /$ nar/gkx1193. 
Table $\mathbf{1}$ (on next page)

LGRs in TS and VS 


\begin{tabular}{|c|c|c|c|c|}
\hline & sample Id & genomic variant & exon deletion & ref \\
\hline \multirow{3}{*}{ TS } & BR59 & c.5407-?_*(1_?)del & exon 23-24 del & $\begin{array}{l}\text { Buffone et } \\
\text { al., } 2007\end{array}$ \\
\hline & BR328 & c.5075-?_5193+?del & exon $18-19$ del & $\begin{array}{c}\text { Buffone et } \\
\text { al., } 2007\end{array}$ \\
\hline & BR409 & NBR2delEX1_BRCA1delEX1-2 & $\begin{array}{l}\text { exon } 1 \text { NBR2 del } \\
\text { exon 1-2 BRCA1 del }\end{array}$ & $\begin{array}{c}\text { Coppa et al } \\
2018\end{array}$ \\
\hline
\end{tabular}

\begin{tabular}{|l|l|l|c|c|}
\hline \multirow{3}{*}{ VS } & BR963 & NG_005905.2: g.163181_169408del6228 & exon 21-22 del & $/$ \\
\cline { 2 - 5 } & BR1154 & NG_005905.2: g.160396_164568del4173 & exon 20 del & $/$ \\
\cline { 2 - 5 } & BR1379 & NG_005905.2:g.145185_151339del6155 & exon 16-17 del & $/$ \\
\hline
\end{tabular}




\section{Table 2 (on next page)}

CNVs prediction by IR software algorithm in TS and VS

The confidence score is the probability that the number of copies of the region of interest is different from 2, which is the normal value, while the confident precision indicates how much the algorithm is certain of the accuracy of the number of copies estimated by the analysis. 


\begin{tabular}{|c|c|c|c|c|c|c|c|c|c|c|}
\hline & Sample ID & Locus & Type & Genes & Location & Length & $\begin{array}{c}\text { Copy } \\
\text { Number }\end{array}$ & CytoBand & $\begin{array}{c}\text { CNV } \\
\text { Confidence } \\
\end{array}$ & $\begin{array}{c}\text { CNV } \\
\text { Precisio }\end{array}$ \\
\hline \multirow{3}{*}{ TS } & BR59 & $\operatorname{chr} 17: 41197602$ & $\mathrm{CNV}$ & BRCA1 & exon $23-24$ & $2.138 \mathrm{~kb}$ & 1 & 17q21.31(41197602-41199740)x1 & 5.66 & 5.66 \\
\hline & BR328 & $\operatorname{chr17:41215277}$ & $\mathrm{CNV}$ & BRCA1 & exon $18-19$ & $749 \mathrm{~kb}$ & 1 & $17 \mathrm{q} 21.31(41215277-41216026) \times 1$ & 13.05 & 13.05 \\
\hline & BR409 & $\operatorname{chr} 17: 41275973$ & $\mathrm{CNV}$ & BRCA1 & exon 2 & $275 \mathrm{~kb}$ & 1 & $17 q 21.31(41275973-41276248) \times 1$ & 1.14 & 1.14 \\
\hline \multirow{2}{*}{$\mathbf{V S}$} & BR963 & $\operatorname{chr17:41201074}$ & $\mathrm{CNV}$ & BRCA1 & exon $21-22$ & $2.18 \mathrm{~kb}$ & 1 & 17q21.31(41201074-41203254)x1 & 9.14 & 9.14 \\
\hline & BR1379 & $\operatorname{chr} 17: 41215855$ & $\mathrm{CNV}$ & BRCA1 & exon $16-18$ & $7.44 \mathrm{~kb}$ & 1 & $17 \mathrm{q} 21.31(41215855-41223295) \times 1$ & 5.11 & 5.11 \\
\hline
\end{tabular}

3

4 


\section{Table 3(on next page)}

Performance of NGS-dependent LGRs analysis

Validation metrics were defined as: Accuracy $=(T P+T N) /(T P+F P+T N+F N)$; Sensitivity $=$ $T P /(T P+F N) ;$ Specificity $=T N /(T N+F P) ; F D R=F P /(T P+F P)$, Negative Predictive Value $=T N /($ $\mathrm{TN}+\mathrm{FN}$ ), where $\mathrm{TP}=$ true positives, $\mathrm{TN}=$ true negatives, $\mathrm{FP}=$ false positives, $\mathrm{FN}=$ false negatives. 


\section{Figure 1}

DQ analyses for TS samples.

(A) for each sample, every peak represents the ratio of the amplicon read count normalized on $B R C A 1 / B R C A 2$ total reads and the average of normalized amplicon read counts from all samples on a single chip (DQA). (B) for each sample, every peak represents the ratio of the amplicon read count normalized on BRCA1/BRCA2 total reads and the average of the coverage data of a baseline built from 127 LGRs negative samples (DQB1). The threshold= mean $\pm 2 S D$. Value $>$ mean \pm 2 SD is indicative of a duplication; Value $<$ mean \pm 2 SD is indicative of a deletion. * indicated the amplicons included in the region involved in the rearrangement as confirmed by MLPA analysis. 
A

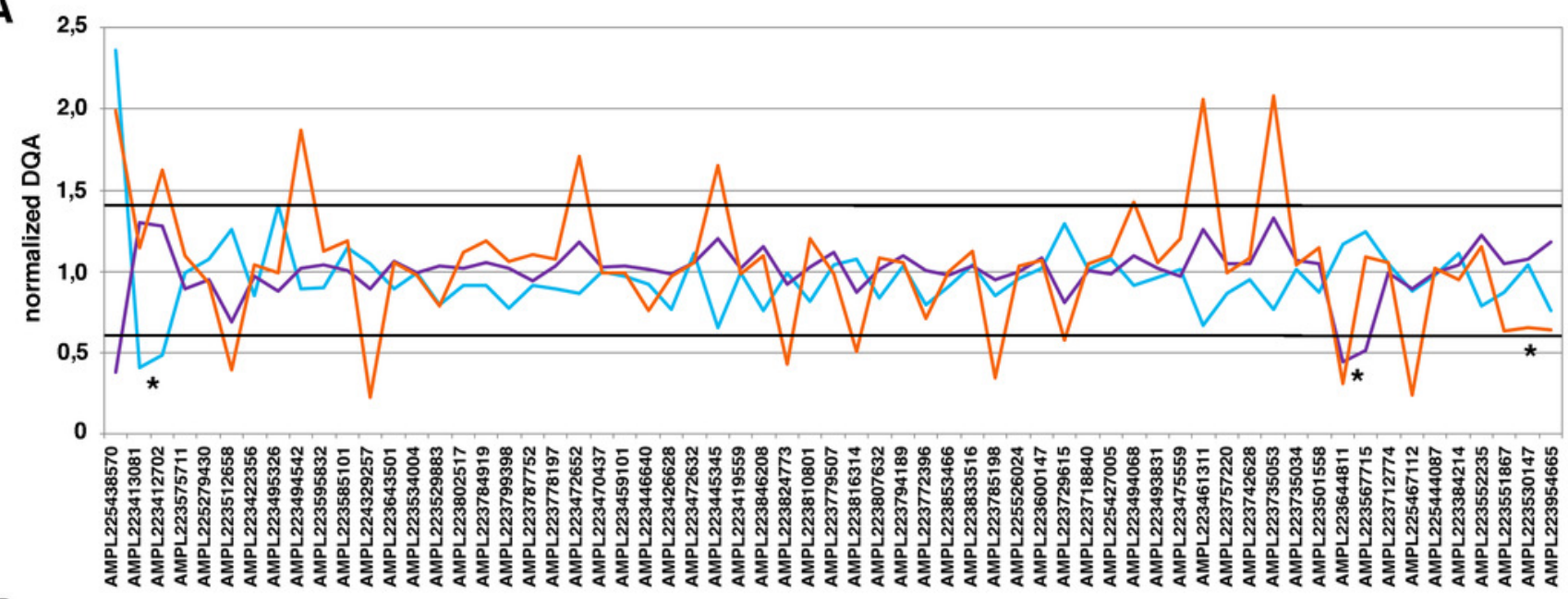

B

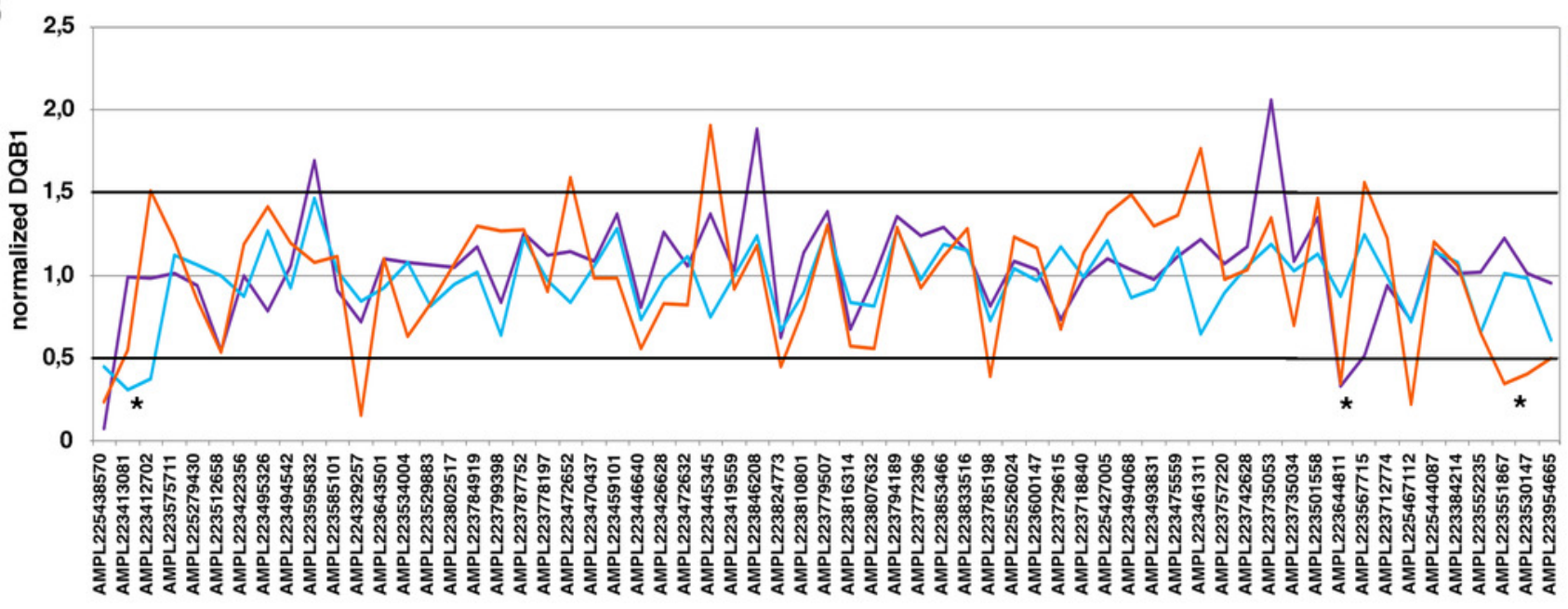


Figure 2

BRCA1 MLPA electropherogram showing aberrant profiles in BR963, BR1154, and BR1379 patients.

(A) Wild-type sample (WT). Black arrows indicate the deletion of (B) BRCA1 exons 21-22 (BR963), (C) BRCA1 exon 20 (BR1154), (D) BRCA1 exons 16-17 (BR1379).

A

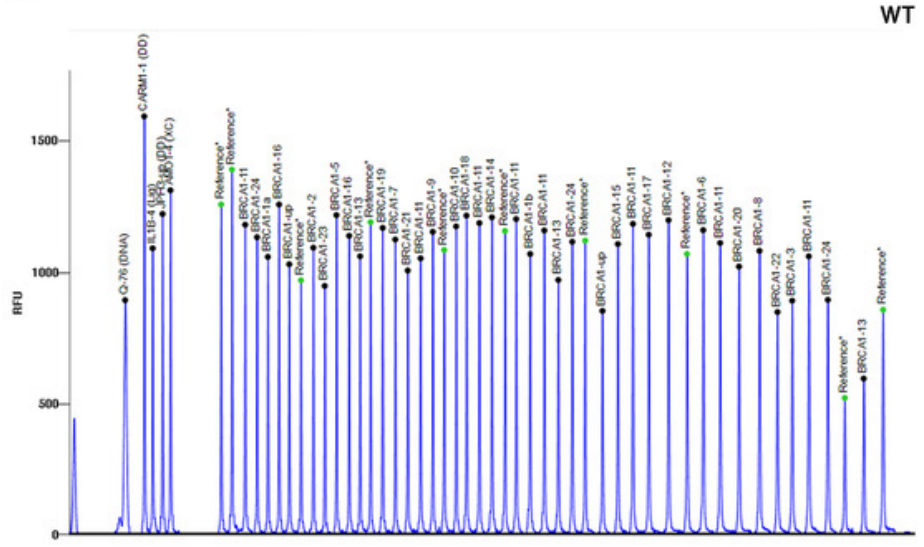

C

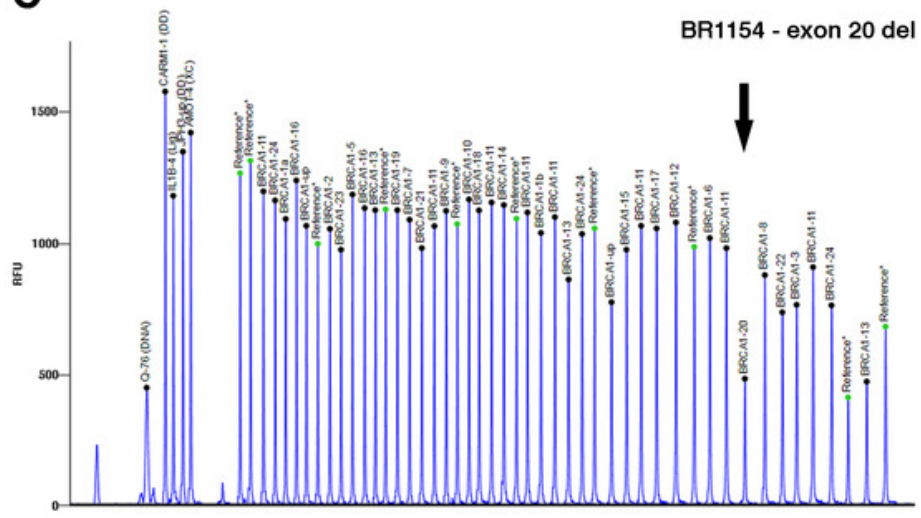

WT
B

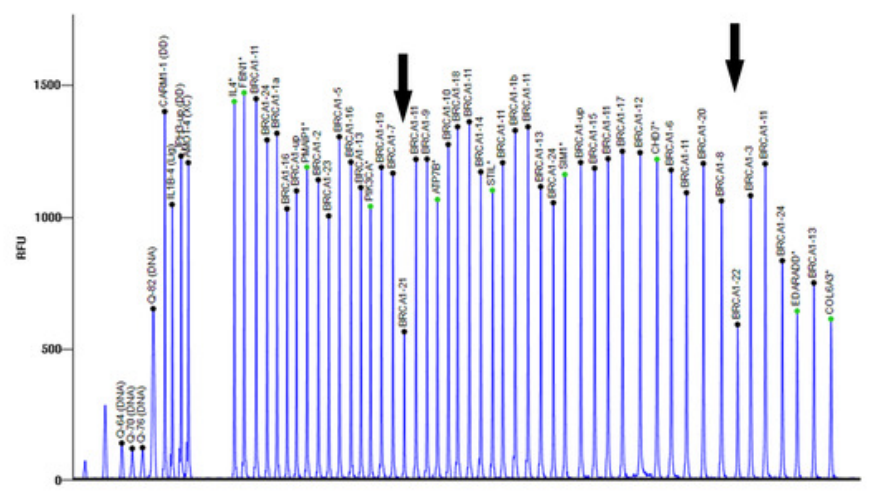

D

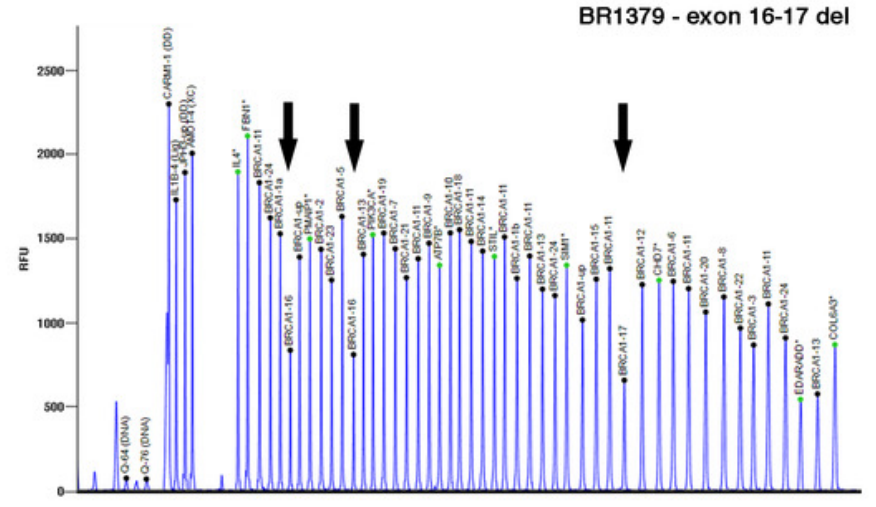




\section{Figure 3}

DQ analyses for the representative samples for VS

(A) and (B) for each sample, every peak represents the ratio of the amplicon read count normalized on BRCA1/BRCA2 total reads and the average of normalized amplicon read counts from all samples on a single chip (DQA). (C) for each sample, every peak represents the ratio of the amplicon read count normalized on BRCA1/BRCA2 total reads and the average of the coverage data of a baseline built from 127 LGRs negative samples considering separately the amplicon pools (DQB2, pool 2). The threshold= mean $\pm 2 \mathrm{SD}$. Value $>$ mean \pm $2 \mathrm{SD}$ is indicative of a duplication; Value $<$ mean $\pm 2 \mathrm{SD}$ is indicative of a deletion. * indicated the amplicons included in the region involved in the rearrangement as confirmed by MLPA analysis. 
A

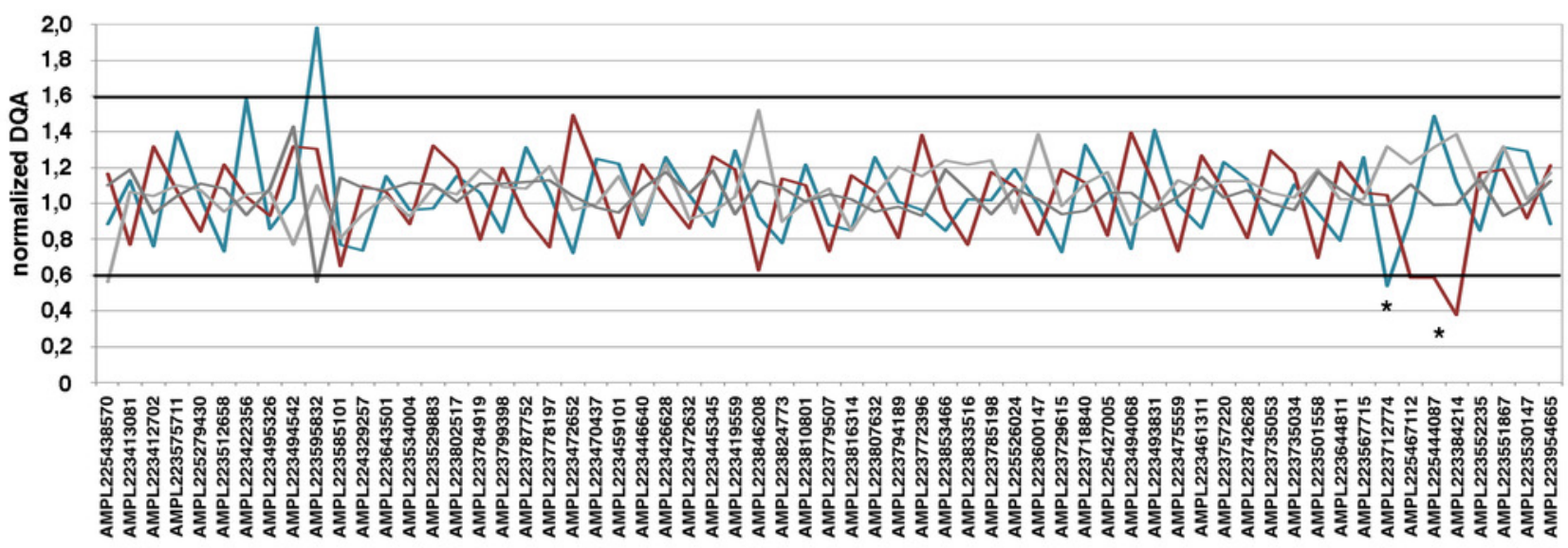

B

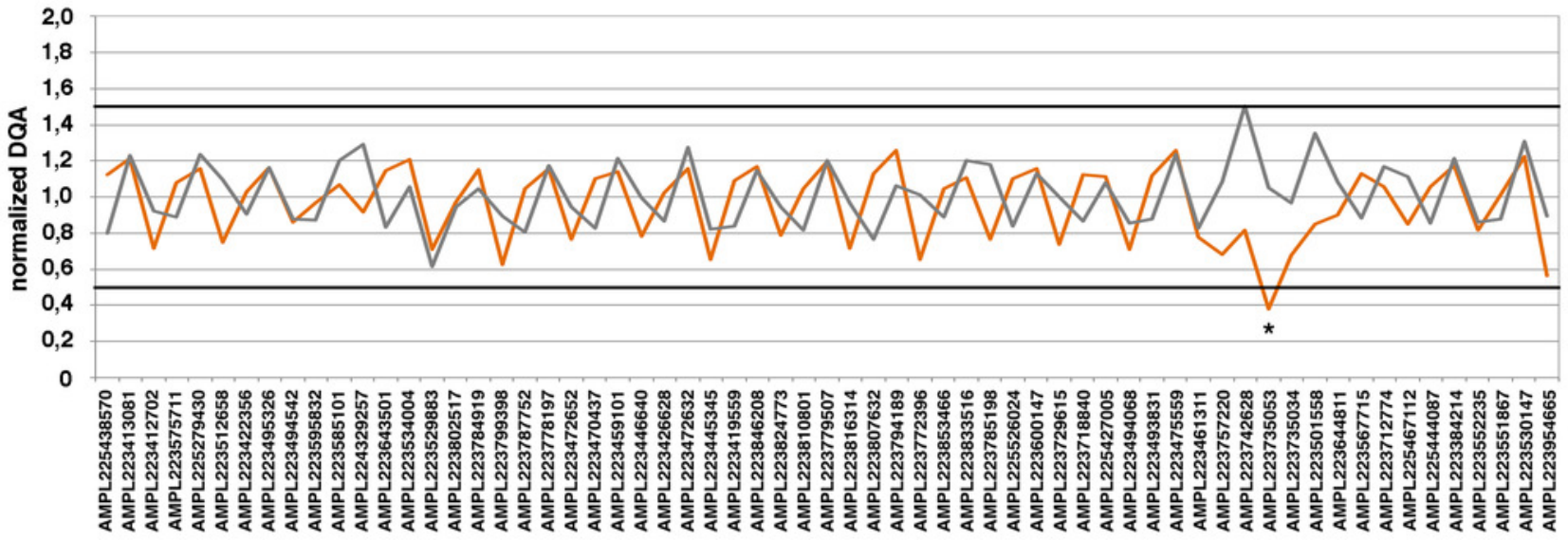

C

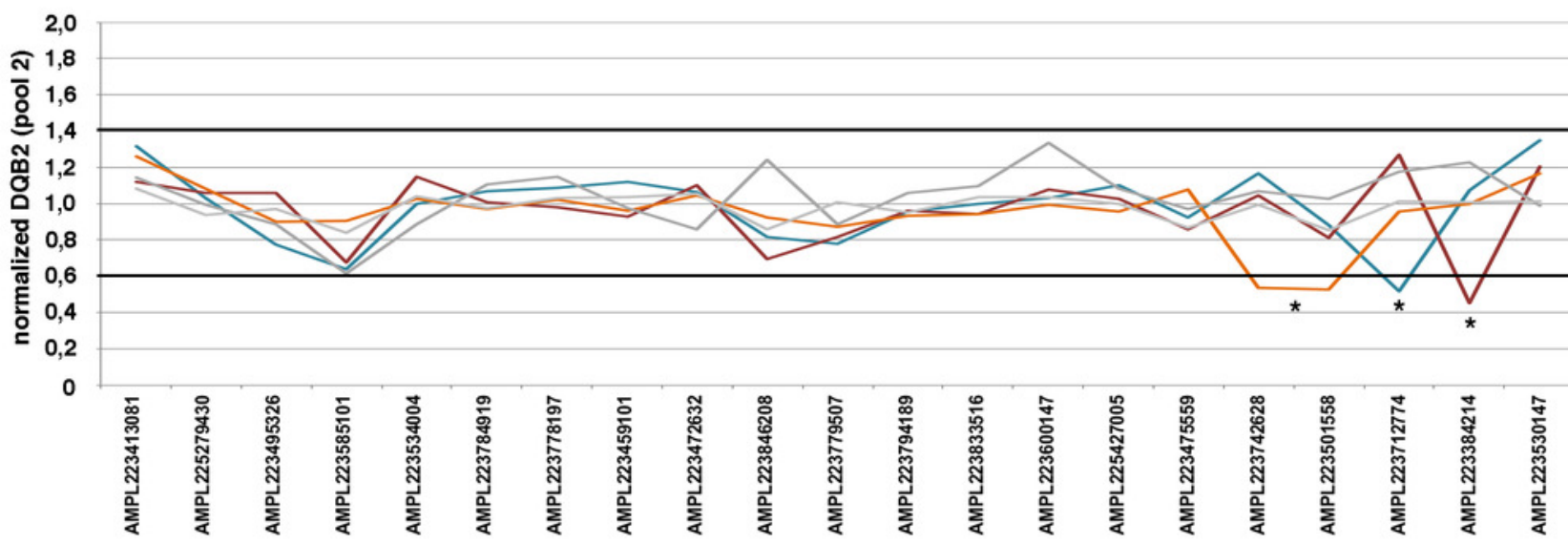




\section{Figure 4}

Characterization of BRCA1 LGRs

(A) gel image of PCR products. PCR amplification of the genomic region spanning the $B R C A 1$ rearrangement resulted in a fragment of approximately 1353 bp present only in the proband BR963. (B) and (C) schematic representation and electropherogram showing the BRCA1 exons 21 and 22 deletion. The variant arose from an erroneous homologous recombination process between an AluSq2 (Alu family, SINE class; chr17:41206762-41207066) and an AluSz (Alu family, SINE class; chr17:41200521-41200834) motif, and it involved a perfectly repeated stretch of $24 \mathrm{bp}$. (D) gel image of PCR products. PCR amplification of the genomic region spanning the $B R C A 1$ rearrangement resulted in a fragment of approximately $872 \mathrm{bp}$ present in the proband BR1154 and in her mother BR1148. (E) and (F) schematic representation and electropherogram showing the BRCA1 exon 20 deletion. The variant arose from an erroneous homologous recombination process between two AluY motif at chr17:41205398-41205698 and chr17:41205398-41205698, respectively, and it involved a perfectly repeated stretch of $11 \mathrm{bp}$. (G) gel image of PCR products. PCR amplification of the genomic region spanning the BRCA1 rearrangement resulted in a fragment of approximately 2027 bp present only in the proband BR1379. (H) and (I) schematic representation and electropherogram showing the BRCA1 exons 16 and 17 deletion. The variant arose from an erroneous homologous recombination process between an AluSp motif (Alu family, SINE class; chr17:41224585-41224884) and an AluSg (Alu family, SINE class;

chr17:41218424-41218724) motif, and it involved a perfectly repeated stretch of $16 \mathrm{bp}$. MK, marker; NT, no template; CTR healthy individual DNA. 
BR963 NG_005905.2:g.163181_169408del6228

A

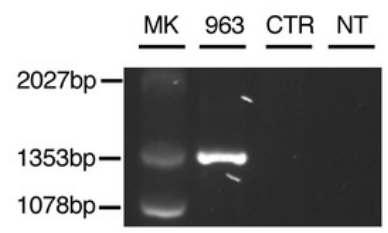

B

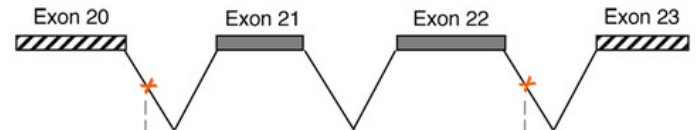

C

chr17:41206820

chr17:41200592

Exon 20 Exon 23

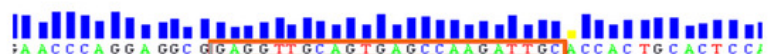

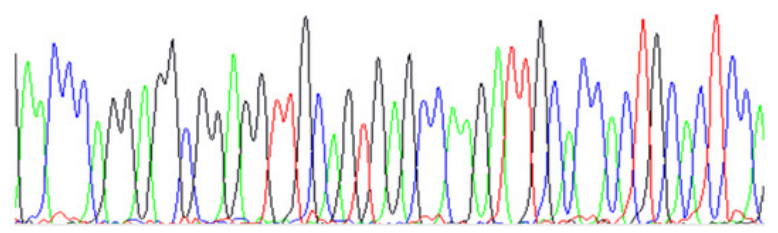

BR1154 e BR1148 NG_005905.2:g.160396_164568del4173

$\mathbf{E}$

D
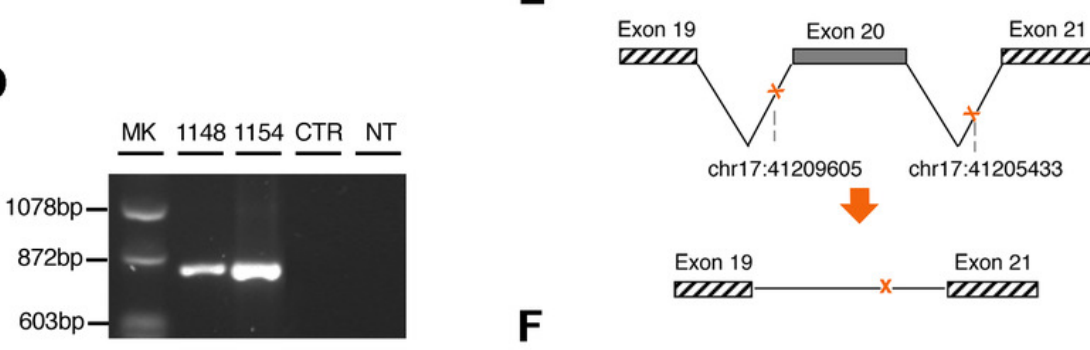

$\mathbf{F}$

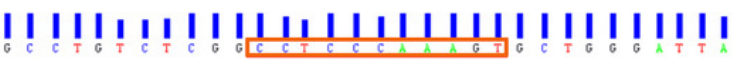

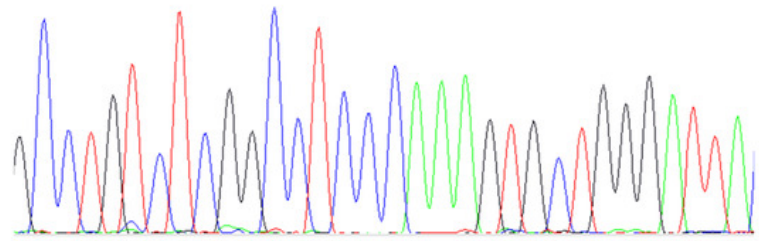

BR1379 NG_005905.2:g.145185_151339del6155

H

G
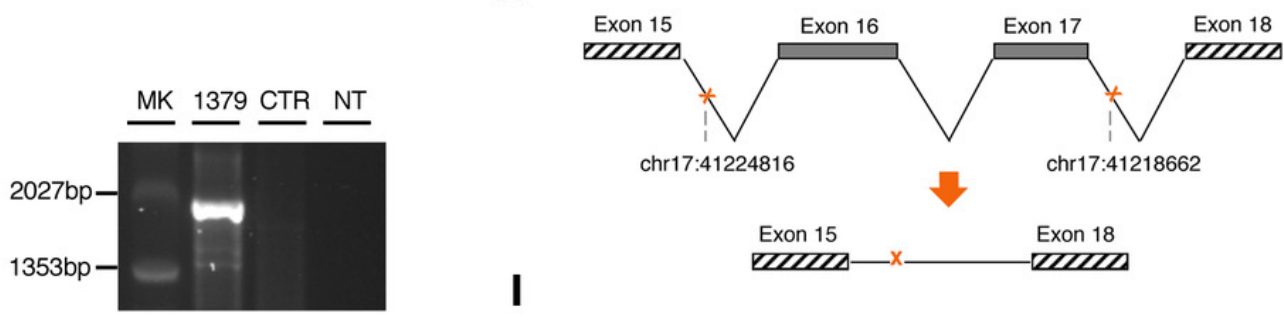

I

I! ! I

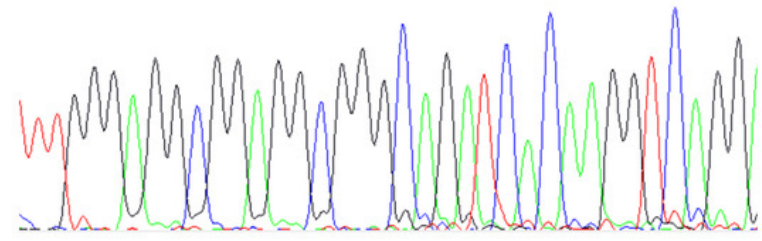


Figure 5

Pedigree of the HBC or HBOC family carriers of BRCA1 novel LGRs

(A) exons 21-22 deletion (BR963). (B) exon 20 deletion (BR1154). (C) exons 16-17 deletion (BR1379). Probands are indicated with an arrow. Cancer type and age at diagnosis are reported and described as: BC, breast cancer; Pan, pancreas; Leu, leukemia; Lung; bil BC, bilateral breast cancer; OC, ovarian cancer; Hep, hepatoma; CC, colon cancer.

A

BR963

BRCA1:NG_005905.2:g.163181_169408del6228

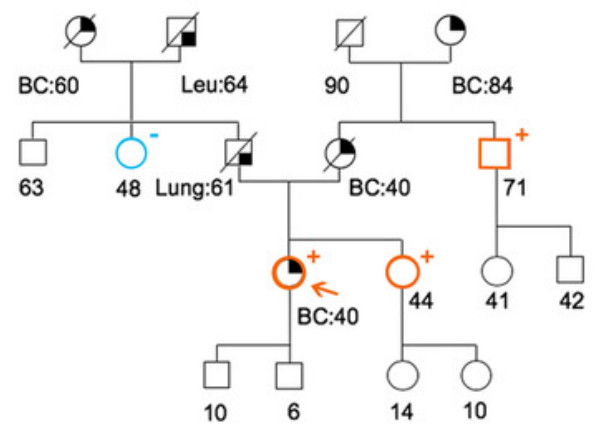

C

BR1379

BRCA1: NG_005905.2:g.145185_151339del6155

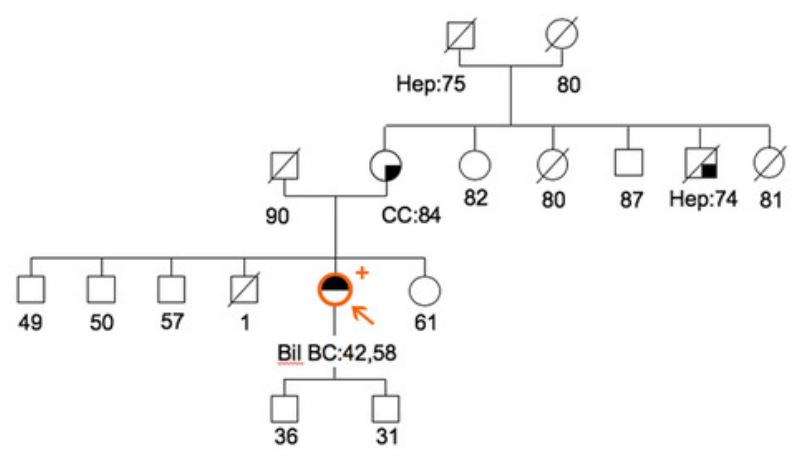

B

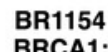

BRCA1: NG_005905.2:g.160396_164568del4173

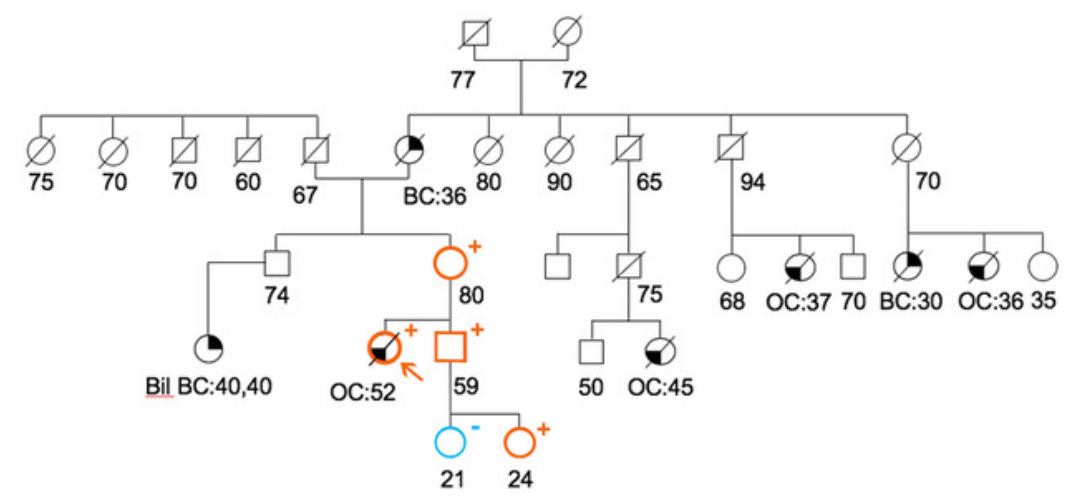


Figure 6

Operative algorithm to select samples for MLPA analysis. 


\section{Coverage Data analysis (average base coverage depth $\geqq 500$ )}

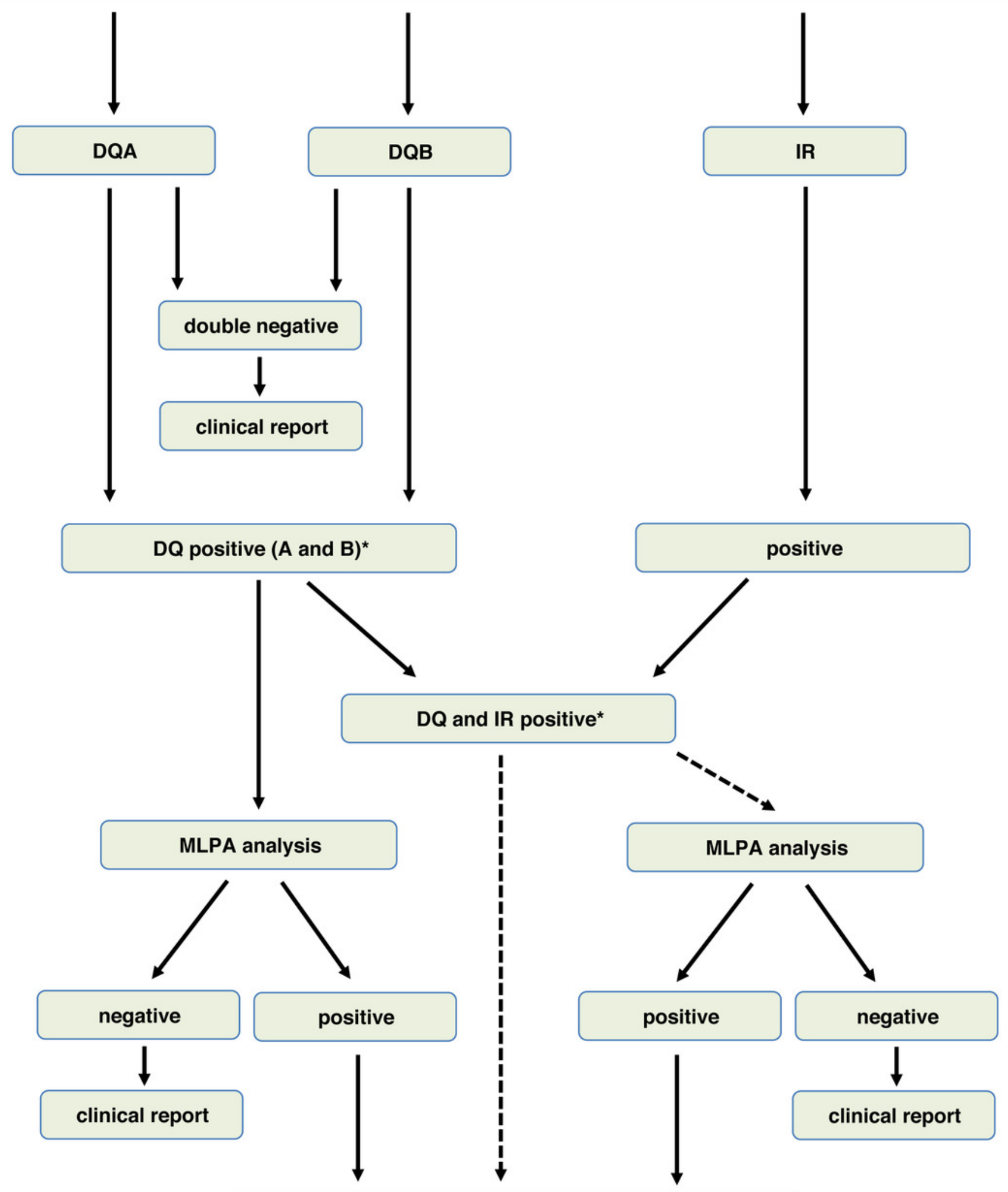

confirmation assays/breakpoint characterization 